\title{
Middle Palaeolithic lithic tools: Techno-functional and use-wear analysis of target objects from SU 13 at the Oscurusciuto rock shelter, Southern Italy
}

\author{
Giulia Marciani ${ }^{1,2,3}$, Simona Arrighi ${ }^{3,4}$, Daniele Aureli ${ }^{3,4,5}$, \\ Vincenzo Spagnolo ${ }^{3}$, Paolo Boscato ${ }^{3}$, Annamaria Ronchitelli ${ }^{3}$ \\ 1. Dipartimento di Studi Umanistici, Sezione di Scienze Preistoriche e Antropologiche, Università degli Studi di \\ Ferrara. C.so Ercole I d’Este 32, 44100 Ferrara, Italy. Email: giulia.marciani@unife.it \\ 2. Department of History, History of Art, Universitat Rovira I Virgili Tarragona. Av. Catalunya, 35, 43002 \\ Tarragona, Spain. \\ 3. Dipartimento di Scienze Fisiche, della Terra e dell'Ambiente, UR Preistoria e Antropologia, Università degli \\ Studi di Siena. Strada Laterina 8, 53100 Siena, Italy. Email: Arrighi: s.arrighi@hotmail.com; \\ Aureli: danieleaureli1@gmail.com; Spagnolo: orpheus.85@hotmail.it; Boscato: paolo.boscato@unisi.it; \\ Ronchitelli: annamaria.ronchitelli@unisi.it \\ 4. Dipartimento di Beni Culturali, Università di Bologna. Via degli Ariani 1, 48121 Ravenna, Italy. \\ 5. UMR 7041 ArScAn équipe AnTET. 21 Allée de l’Université, F 92023 Nanterre, France.
}

\begin{abstract}
:
The Oscurusciuto rock shelter (Ginosa, Puglia, southern Italy) is a Middle Palaeolithic site characterized by a significant stratigraphy made up by several anthropic levels. The stratigraphic unit 13, consisting of a sandy compact deposit mixed with pyroclastic sediment, is a short palimpsest situated on a layer of tephra, identified as Mt. Epomeo green tuff (dated $\mathrm{Ar} / \mathrm{Ar} \sim 55 \mathrm{ka} \mathrm{BP}$ ).

From a technological point of view, the aims of the production were backed flakes, convergent flakes, and other flakes obtained by means of a Levallois debitage, plus (less represented) bladelets produced by an additional volumetric reduction system.

Our aim in this research was to examine a selection of the above-mentioned target objects produced by debitage in order to understand the manufacture and life-cycle of each single tool from a dynamic perspective.

We integrated techno-functional and use-wear analyses: the first was implemented to globally comprehend each tool, identifying each single techno-functional unity (prehensile and transformative portions), whereas the second revealed the way in which these tools had been used, proceeding to identify the activity involved (e.g., piercing, cutting and/or scraping), and the type of material (vegetable/animal, soft/hard) on which these activities had been carried out.

The combined use of these two approaches allows us to ascertain the intention of the prehistoric craftsmen, the gestures and procedures involved in making the tools, and the way they had been used. From one single object we are thus able to reconstruct a series of complex behaviours, encompassing the creation, the life-cycle and finally the 'death' or repurposing of the tool in question.
\end{abstract}

Keywords: technical behaviour; techno-functional approach; use-wear analysis; Middle Palaeolithic; Neanderthals; western Europe

Published by the School of History, Classics and Archaeology, University of Edinburgh ISSN: 2055-0472. URL: http://journals.ed.ac.uk/lithicstudies/

Except where otherwise noted, this work is licensed under a CC BY 4.0 licence. 


\section{Introduction}

The Oscurusciuto site is a Middle Palaeolithic rock shelter located in Southern Italy with a very rich record, essential for the definition of Neanderthals technical behaviour, as related both to the management of the raw material on the territory and the crafting and use of lithic tools. The lithic collections of Oscurusciuto show substantial uniformity even though each level displays its own peculiarity. The acquisition of raw material is local; Neanderthals used pebbles of jasper, chert, cherty limestone and quartz sandstone available in the terraces and areas near the site. The recurrent Levallois method is the most commonly noted concept of debitage especially in its unipolar modality aiming at producing elongated supports, both convergent or not. Furthermore, there is an additional volumetric exploitation aiming at producing bladelets (Boscato et al., 2011; Marciani, 2013; Marciani et al., 2016; Ranaldo, 2005; 2017; Ronchitelli et al., 2011; Spagnolo, 2013; 2017; Spagnolo et al., 2016; Villa et al., 2009).

As it is widely known, the Levallois reduction sequence is an integrated concept that allows for the production of a great quantity of predetermined products with specific characteristics and dimensions (Boëda, 1991; 1993; 1994; 1995; 2013; Schlanger, 1996; Van Peer, 1992). The degree of predetermination of this concept regards both obtaining of a certain quantity of target products (resulting from the lineal lpreferential or recurrent Levallois debitage) and their quality (Boëda, 1991; 1993; 1994; 1995; 2013). It also testifies to a specific economic strategy with regard to the maximization of cutting edge productivity obtained from cores (Brantingham \& Kuhn, 2001; Lycett \& Eren, 2013).

The Levallois production at the Oscurusciuto stratigraphic unit 13 was aimed at producing a clear set of debitage goals: flakes, convergent flakes and backed flakes. In previous studies we have noted the peculiar and recurrent features of these objects and their particular role in the economy of the level (Marciani, 2013; Marciani et al., 2016). We assumed that these target objects had been imported as finished objects into the site, or had resulted from an in situ debitage process (Marciani, 2013; Marciani et al., 2016; Spagnolo et al., 2016).

As the target objects are the answer to specific needs and necessities which motivated the flaking activity itself (Boëda, 2013), we examined the role played by Levallois target objects in the society where they were produced. In particular, our main objective for this work was to focus on the Levallois target flakes produced at Oscurusciuto SU 13. We wanted to test (1) if the target objects of a reduction sequence (the production-aim), were actually used by Neanderthals to perform their activities (the functional-aim); (2) if each production-aim corresponded to a single functional-aim i.e. each tool was used solely for one activity, or, on the contrary, if it was used for a multitude of purposes; and finally (3) if tools used for a specific activity also had a specific structure.

To accomplish these goals we integrated techno-functional and use-wear analyses: the first was implemented to globally comprehend each tool, identifying each single technofunctional unity (prehensile and transformative portions), whereas the second revealed the way in which these tools had been used, proceeding to identify the activity involved (e.g., piercing, cutting and/or scraping), and the type of material (vegetable/animal, soft/hard) on which these activities were carried out.

From a methodological point of view, we note that both techno-functional and use-wear analyses have been applied on several lithic assemblages coming from diverse archaeological contexts and periods (e.g., Boëda, 1997; 2001; Soriano, 2000; Da Costa, 2017; Lourdeau, 2010), however few works have attempted to combine them (Aureli et al., 2015; 2016; Boëda et al., 2015; Bonilauri, 2010; Pedergnana, 2017). In the case of the site of Ficoncella (Rome Italy; dated back to 500,000 years BP), the combined use of techno-functional and use-wear 
approaches was essential to determine the technical structure and the peculiarities of some active unities (trihedral, mini-rostrum and brute cutting edge) barely described before in lower Palaeolithic literature (Aureli et al., 2015; 2016). Another outstanding example is the case of Umm el Tlel site (central Syria - dated back to 40,000 years BP). Here the authors were able to evidence the technical role of the bladelets. These very well-known tools actually resulted from different production systems, performed several tasks, and were hafted in different ways (Boëda et al., 2015).

The challenging point about applying these two approaches together is that there is an added value by their combined use. In fact, the technological analysis permits us to understand the production procedure of lithic tools, and the techno-functional analysis allows us to understand the structure of the tools, as well as the functional potential of the parts constituting the tools. Finally, the use-wear analysis verifies or rejects these hypotheses. Tracceologists can also use the techno-functional study as a proxy for the selection of their samples, i.e. defining significant criteria to select the pieces to analyse, and examining traces guided by technical parameters. It is worth remembering that these approaches work in a continuous dialogue, comparing and integrating the observations from each approach.

As a matter of fact our contribution with this paper is to demonstrate the complementarity and added value of combination of these approaches, which produce new and stimulating insights into "the ways of existing" of prehistoric technical objects (Du mode d'existence des objets techniques Simondon, 1958)

\section{The site}

The Oscurusciuto rock shelter is situated in the region of Puglia, Southern Italy, namely in the ravine of Ginosa (Taranto) (Figure 1).

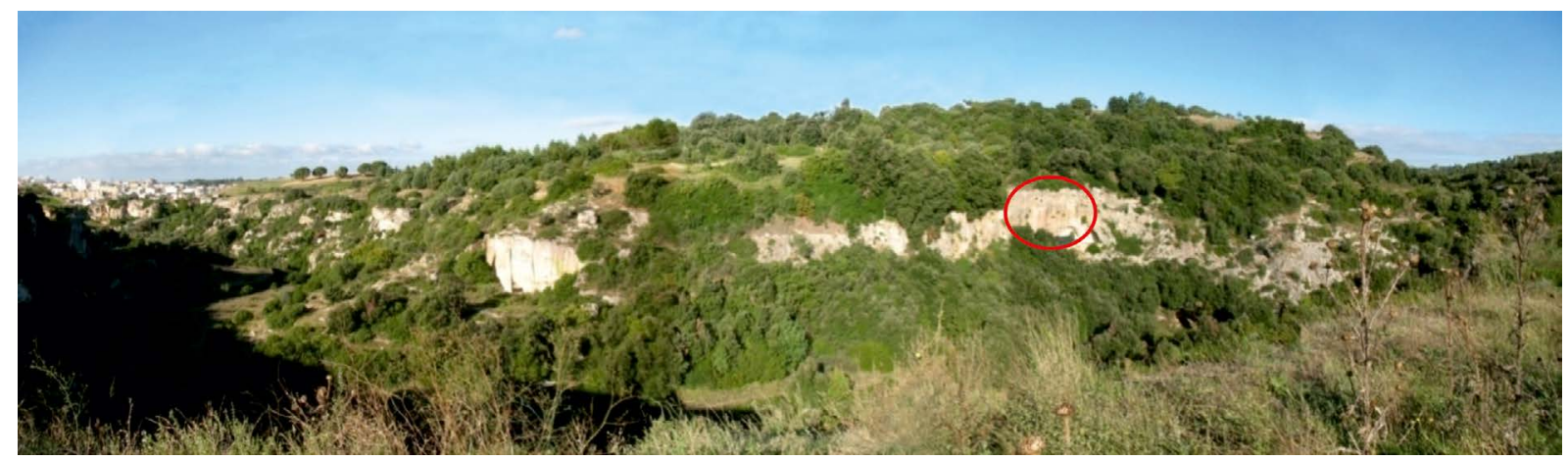

Figure 1. Panoramic view of the ravine of Ginosa, in the red circle the Oscurusciuto rock shelter (Photo A. Ronchitelli).

The site, opened into the Pleistocene calcarenite (Calcareniti di Gravina), stands at an elevation of $235 \mathrm{~m}$ above sea level, at about 15 meters from the current bottom of the ravine, and at about $20 \mathrm{~km}$ far from the actual Ionic coastline (Figure 2).

The archaeological deposit measures $60 \mathrm{~m}^{2}$ at its base, and has a thickness of more than 6 meters. This sequence extension downwards gradually increases because the hill erosion damaged the deposit in the shelter, especially on the upper layers (Figure 3). Since 1998 until the present day, the first 3 meters of the sequence corresponding to nine main Middle Palaeolithic occupation phases have been investigated by the U.R. "Preistoria e Antropologia" under the "Dipartimento di Scienze Fisiche, della Terra e dell'Ambiente - University of Siena, Italy".

The chronological limits of the Neanderthal occupation of the rock shelter are obtained by two dates. The first, obtained by the C14 method (on collagen), is referred to the bottom of 
SU 1 which is datable to 38,500 $\pm 900 \mathrm{BP}$, cal. 42,724 \pm 716 BP Beta 181165 (Ramsey \& Lee, 2013; Reimer et al., 2013). The former derives from the identification of the tephra layer (SU 14) as Mount Epomeo green tuff (Marciani et al., 2016; Spagnolo et al., 2016) datable to about 55,000 BP (Allen et al., 2000).
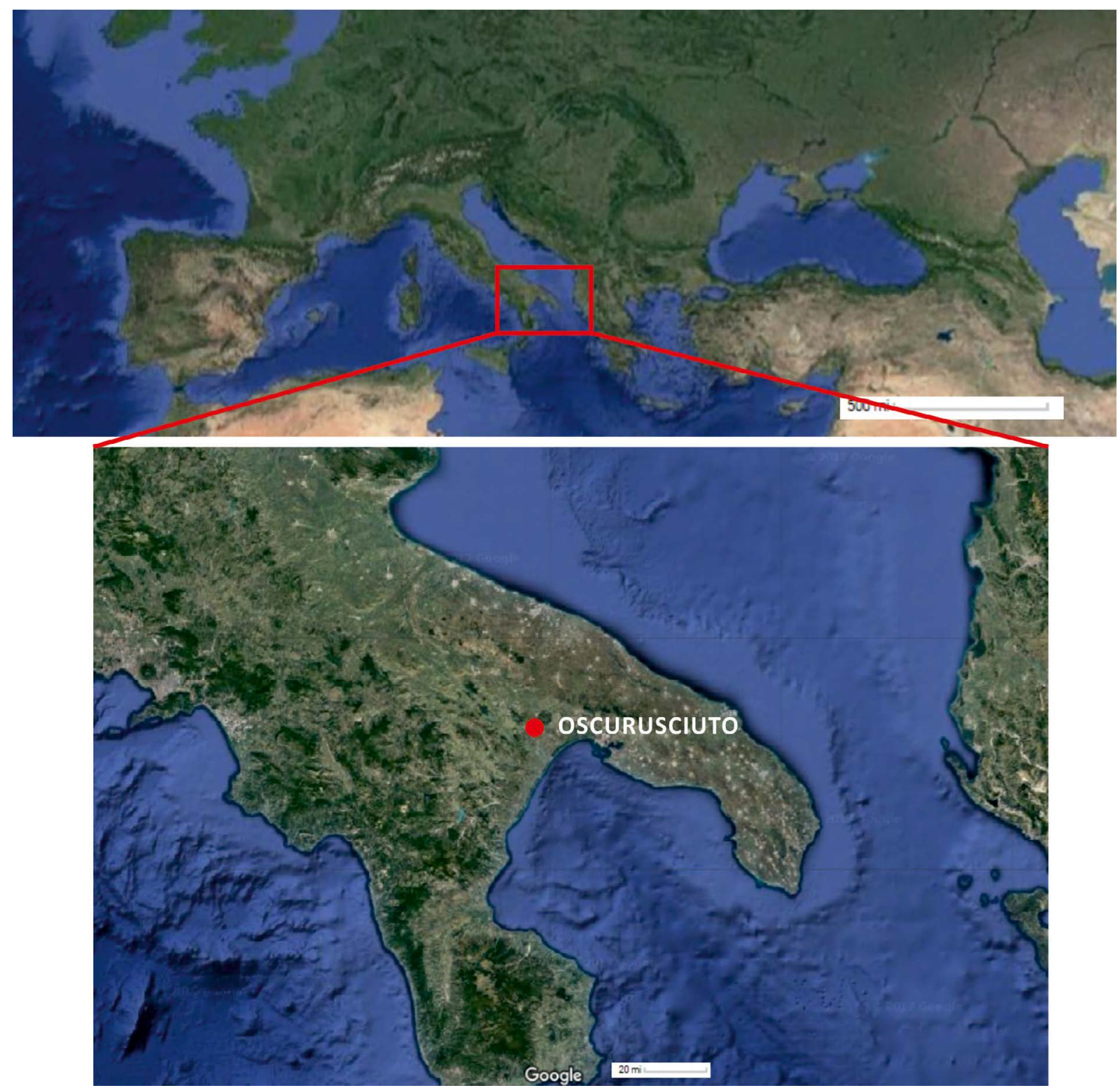

Figure 2. Location of Oscurusciuto (Modified from Google Maps).

The faunal associations found at Oscurusciuto are characterized by the main presence of Bos primigenius, Equus ferus, Cervus elaphus and Dama dama in different variations and associations, which show both little paleo-climatic fluctuations and the coexistence of different biomes, possibly related to a micro-scale landscape variability linked to the ravine environment. Essentially, the studied samples (from SU 15 to SU 1) show that the Neanderthal hunters exploited two different environments: a forest-steppe area, probably present on the hilly relieves, and a moister territory with wooden coverage, inside the ravine (Boscato \& Crezzini, 2012; Boscato, 2017).

SU 13 (Figure 4) consists of the sedimentary interface between the SU 11, sandy layer above, and the SU 14, the proper tephra deposit. It represents the first stable re-colonization of the rock shelter which occurred during the final phase of volcanic ashes deposition (Marciani 
et al., 2016; Spagnolo et al., 2016) (Figure 3). It is a short palimpsest excavated for the extension of 11 square meters. The level is characterized by the presence of quite abundant faunal remains; however, only six elements were identified, due to high fracture grade $(1=$ Equus ferus and $5=$ Bos primigenius). Above SU 13 a series of structured hearts made in prepared dimple was exposed which seems to be arranged in a line that divides the space of the rock shelter into two portions: inside and outside the line of fires (Spagnolo et al., 2016).

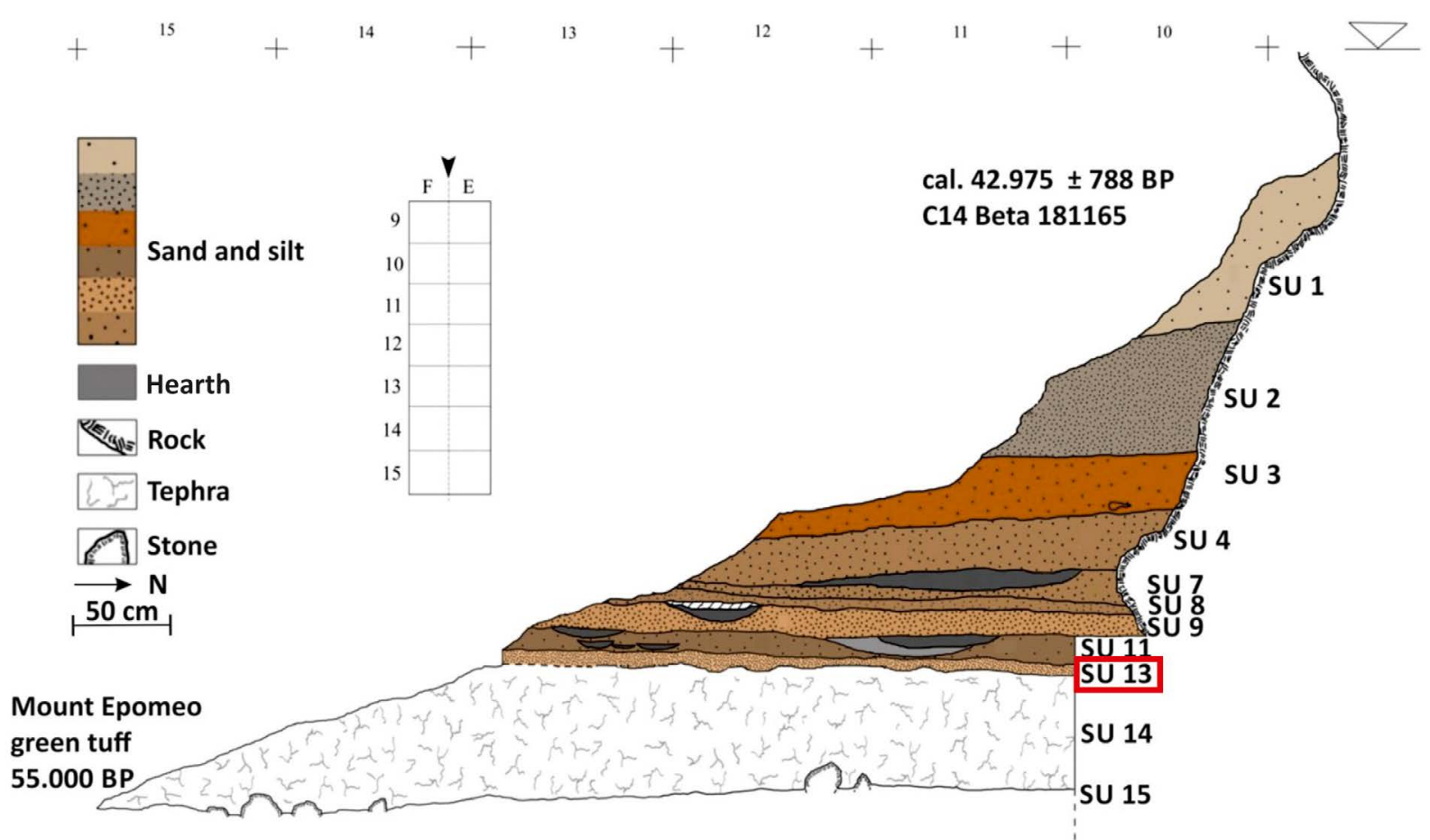

Figure 3. Stratigraphic sequence of the upper portion of Oscurusciuto rock shelter (sequence so far excavated) (Relief made by P. Boscato; drawing by A. Ronchitelli).

\section{Material and methods}

\subsection{Lithic production}

In SU 13, 7504 well preserved lithic artefacts were found. As in all the upper stratigraphic units, the dominant raw materials are jasper and cherty limestone in their fine granulometry, found in the form of pebbles, which can still be found on the sea-terraces and river deposits around the site (nowadays almost between few tens of meters and over than 20 $\mathrm{km}$ far from the site) (Marciani, 2013; Marciani et al., 2016).

The occupation of SU 13 is a short palimpsest that was possible to disentangle in at least two (if not most) settlement events (Spagnolo et al., 2016; Spagnolo, 2017). The lithic collection corroborates this idea because there are several fragmented reduction sequences. Namely, the lithic material was entered into the site at different stages of debitage, which means in the form of rough objects (pebbles), or as semi-finished items (decortication happened outside the rock shelter), and as finished tools (target objects or retouched tools). However, there is evidence of pieces exported from the site, especially the target objects. Only 30 pieces have been retouched (Marciani et al., 2016).

Only two concepts of debitage were utilized at the level 13: the Levallois concept and the additional volumetric reduction sequence. Namely, the latter refers to an additional production aimed at producing bladelets where the striking platform is prepared but the convexities are not prepared and only the natural convexities of the raw block are used, i.e. C2 type of cores according to Boëda classification (Boëda, 2013). 
In this paper, we will focus only on the Levallois products: flakes, convergent flakes and backed flakes. From a totality of 385 target pieces (Marciani, 2013; Marciani et al., 2016) we selected 312 target objects with clearly recognizable technical features (fragmented or postdepositional altered pieces were excluded from the study).
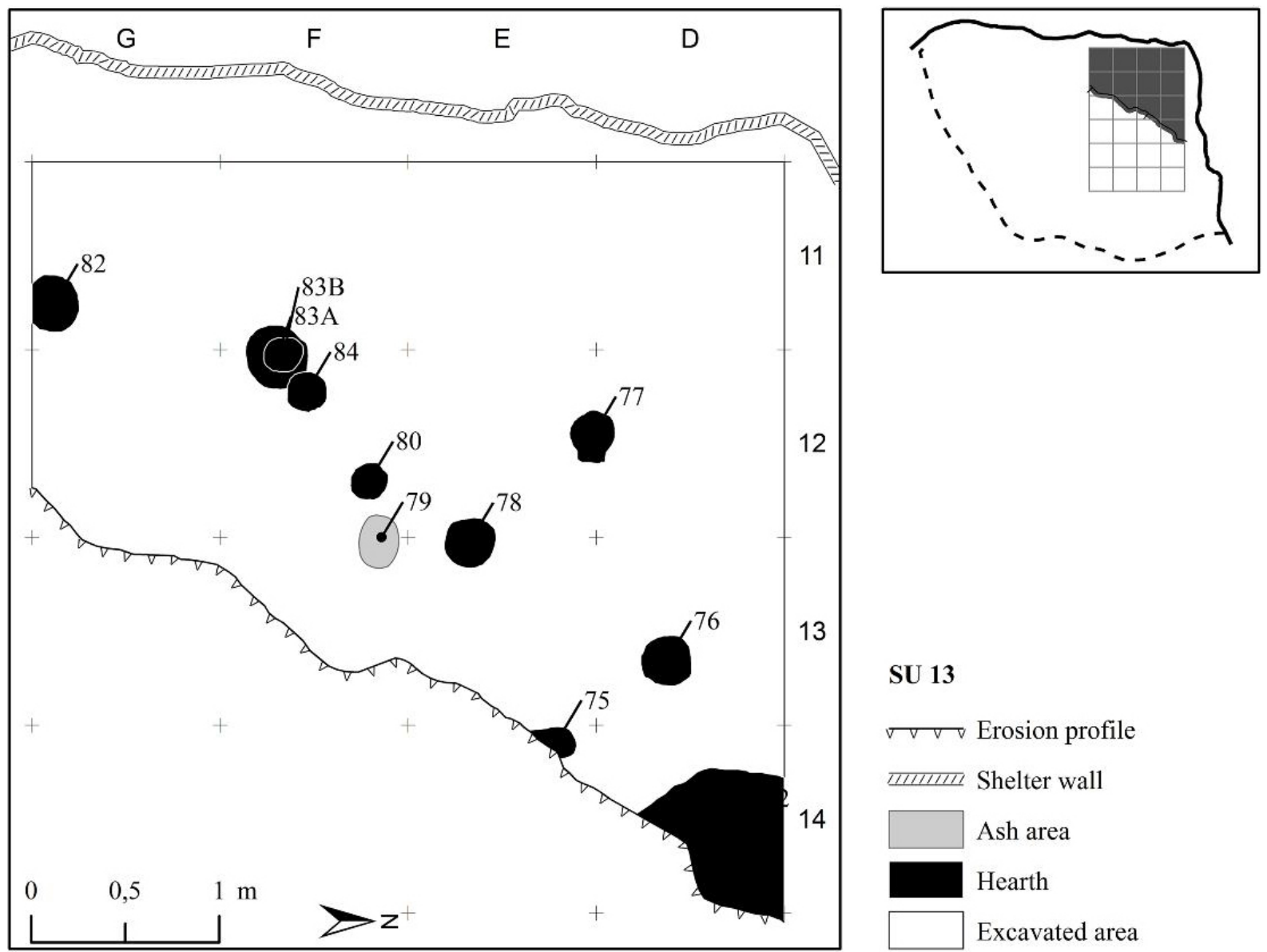

Figure 4. SU 13 planimetry (Relief made by Boscato, draw by Spagnolo).

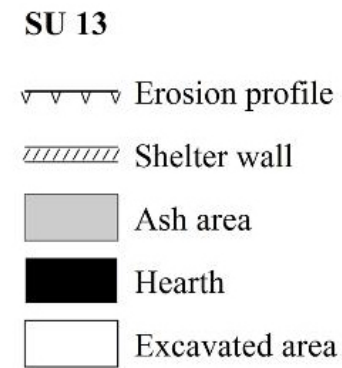

In the text we refer to the objective of debitagelend-products with the expression "target objects" (target flakes, target blade, etc.) because we think that even if not very common in bibliography it expresses very well the strong degree of intentionality used in order to produce them.

\subsection{Techno-functional analysis}

The techno-functional analysis is the study of the structure and potentiality of tools which are defined as objects consisting of three main parts: transformative part, transmitting part and prehensile part. These parts are defined as techno-functional unities: the UTFt transformative techno-functional unit corresponds to the active portion of the tool plus the edge, which is the part which actually enters into contact and modifies the material; the UTFp - prehensile techno-functional unit is the holding portion. Between those there is the transmitting techno-functional units (UTFtr) which is conceived as an intermediate factor transmitting the force from the handle to the transformative portion (Boëda, 1997; 2001; 2013; Bonilauri, 2010; Da Costa, 2017; Lepot, 1993; Lourdeau, 2010; 2015; Soriano, 2000).

The techno-functional unities are indispensable for the tool operation, as is the synergy between them that makes the tool capable of realizing an action. Identifying these parts and understanding their synergy enables us to understand the potential capacity of each single 
tool. Furthermore, in addition to prehensile, active and transmitting parts, we should not forget the role of the gesture. Namely, the specific gesture involved in moving a tool is indispensable for the proper functioning of the tool, whereby we mean the kind of action, as well as the actual movement, both of which made the tool technically worthwhile (Leroi Gourhan, 1973).

The identification, location and characterization of UTFt and UTFp lay in empirical observation of the objects and collection of objective data. Whereas the identification of the transmitting part is much more difficult to perceive, for this reason in this work we consider together the prehensile and transmitting parts (Boëda, 2001; Bonilauri, 2010; Da Costa, 2017; Lourdeau, 2010; Soriano, 2000).

After analysing each single piece, comprising the identification, characterization and localization of each UTF, we have identified groups of pieces that share the same structural composition, i.e. techno-type. Going more in detail, a techno-type is defined by pieces with the same number and characteristic UTFt; and the same position and number of UTFp. The sub-types are inner variations of techno-types in our case expressed by the delineation and position of cutting edges. After defining the techno-types and sub-types, i.e. the combination of UTFt and UTFp, we have identified how these combinations were arranged on each blank.

\subsubsection{Defining the blank}

The blank is actually the support on which the UTFt and UTFp are installed. At Oscurusciuto SU 13 we defined blanks on the basis of four parameters: shape, section, elongation index and size of the pieces.

The shape is rectangular, when there are 2 parallel $\backslash s u b$ parallel edges plus a transversal edge (these edges could be sharp of backed; in this group trapezoidal and oval shapes are also considered). Alternatively, it is described as triangular when there are 2 edges converging into a point (Figure 5). The section of the piece takes into consideration the section-shape of the items but also the number of cutting edges. This means that triangular and trapezoidal pieces have 2 cutting edges, whereas rectangular-triangle and rectangular-trapeze have only one cutting edge opposed to a backed side (Figure 5). The elongation index is given by the ratio between height and width. If the result is less than 1.4 it is a flake, if the result is comprised between 1.5 and 2 it is a long flake, if the result is major then 2.1 it is a blade (Figure 5). The size of the pieces is based on the graphic of dispersion of the height of these pieces of Oscurusciuto SU 13. We define a piece as "small" if its maximum height is until $20 \mathrm{~mm}$, "medium" if it is comprised between 21 and $34 \mathrm{~mm}$ and "big" if its height is higher than 35 mm (Figure 5).

\subsubsection{Defining transformative parts (UTFt)}

We identified two types of UTFt: the cutting edge and the trihedron. The cutting edge is a dihedron made up by the intersection of two surfaces, which delimits a plan section and an angle able to cut (Lepot, 1993; Soriano, 2000). In order to define the cutting edges we consider its delineation (from frontal and profile view, which could be: rectilinear, convex, concave and denticulate), location (distal, mesial, proximal, mesio-distal, mesio-proximal; left or right), extension (expressed in $\mathrm{mm}$ ) angles, and surfaces relation (Plan/Plan; Convex/Plan; Concave/Plan; Convex/Convex; Concave/Concave) (Abruzzese et al., 2016; Boëda, 1997; 2001; Bonilauri, 2010; Da Costa, 2017; Lepot, 1993; Lourdeau, 2010; Lucas, 2014).

The trihedron is defined as a geometric figure composed of three planes meeting at a single vertex. As UTFt the trihedron is a punctual UTF, which means that it does not have an extension. In order to define the trihedron we consider its location, surface relations, angles, that is the angle made by the surfaces (section plan between ventral and dorsal surface of the 
item) and the openness angles which is the angle made by the two lateral sides (left and right side of the items) (Aureli et al., 2016; Rocca, 2013) (Figure 6).

\section{SHAPE}
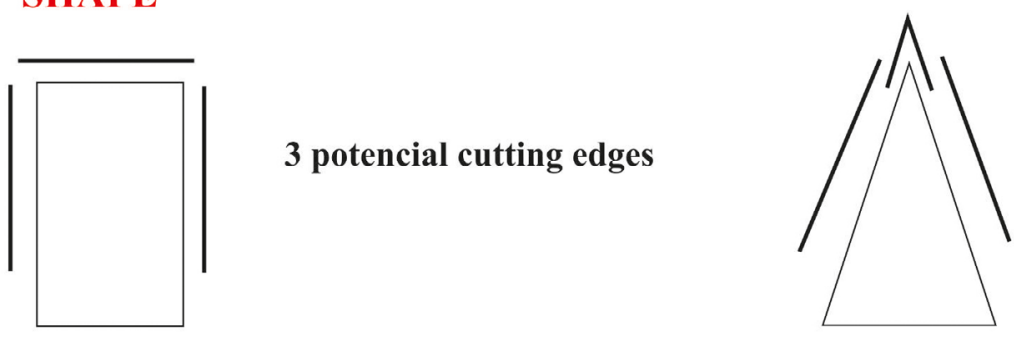

2 potencial cutting edges

3 potencial cutting edges plus distal convergent edge

\section{SECTION}
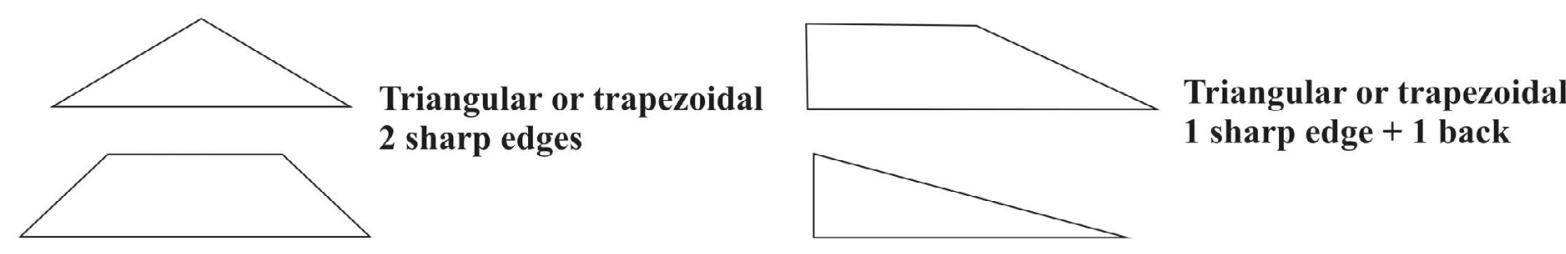

\section{ELONGATION INDEX}

SIZE

H: Height

W: Width

\begin{tabular}{|c|}
\hline$H \backslash W$ \\
$=<1,5$ \\
Flake
\end{tabular}
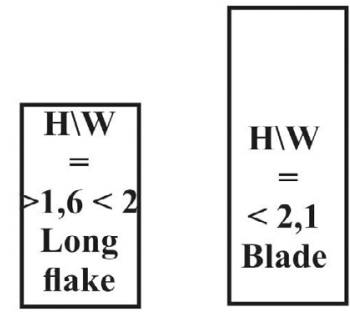

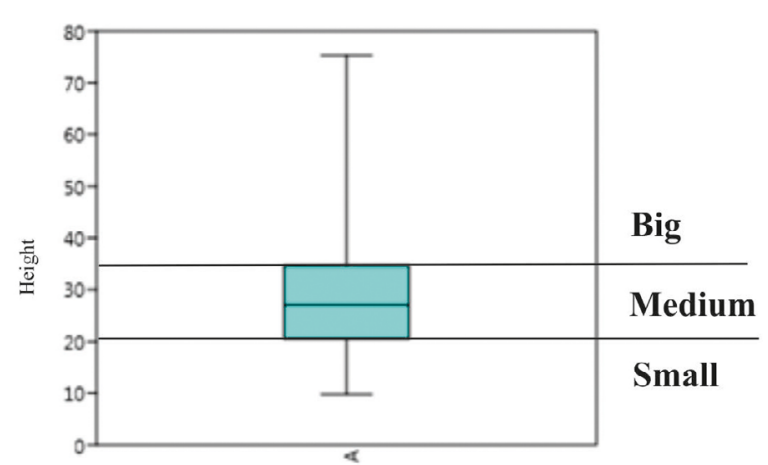

Figure 5. Shape, section, elongation index and size of the pieces (the size is based on the height of the pieces box plot realized with Past 3.16).
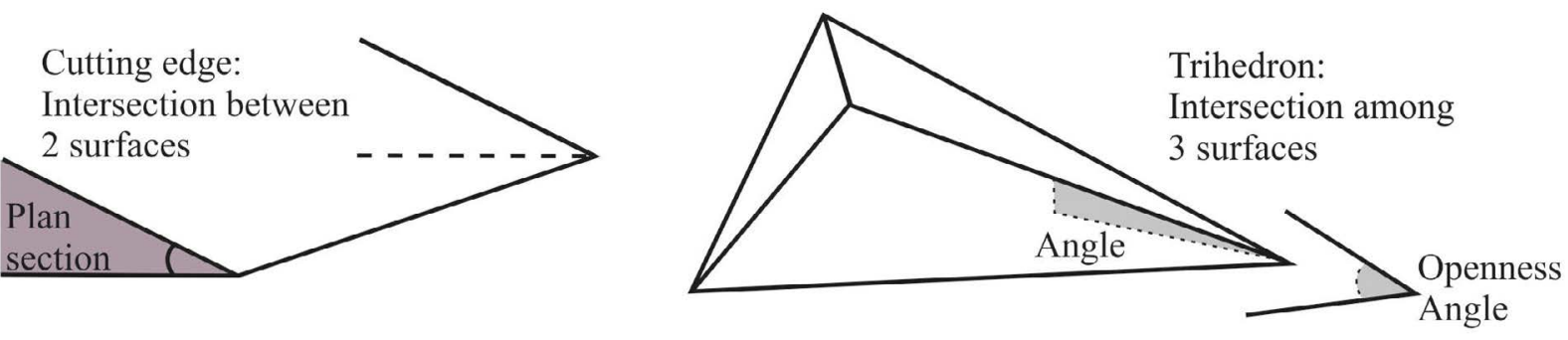

Figure 6. UTFt cutting edge and UTFt trihedron.

If there is more than one UTFt on the same blank we register which kind of relation exists between them: contiguous if the two (or more UTF) are in an adjacent position and in contact between them, and opposed if the two (or more UTF) are in front of each other. All the parameters are considered with the flake oriented in the technological axis. 


\subsubsection{Defining prehensile parts (UTFp)}

In the absence of evident grip-traces or glue residues, so far, we consider as potential UTFp all the backed sides, the cortical edges and more in general a discontinuous and irregular edges (Soriano, 2000). The butt is also considered as potential grip, in fact especially for Levallois chapeau de gendarme, the ergonomic features of its shape are already attested in experimental studies (Baena Preysler et al., 2016). We consider the thickness, location, angles and extension of UTFp. A notable parameter when defining the structure of a tool is the relation between backed sides i.e. a single backed side, two continuous backed sides, two opposed backed sides, or three framed backed sides (Da Costa, 2017).

\subsection{Use-wear analysis}

The use-wear analysis was performed on 34 items identified as Type-blank A (see paragraph 4.1). The study was carried out by means of both the low power approach (LPA) (Odell, 1981; Odell \& Odell-Vereecken, 1980; Tringham et al., 1974, and for more recent discussions or applications see Lemorini, 2000; Plisson, 2007; Rots, 2010) and the high power approach (HPA) (Keeley, 1980; Plisson, 1985; Van Gijn, 2010).

LPA is focused on analysis and interpretation of macro use-wear (edge-removals, edgerounding) while HPA is based on the observation of micro use-wear (micro edge-rounding, polishes, striations).

Macro use-wear was observed at low magnification (20x - 80x) by means of a Hirox KH 7700 3D digital microscope, using a MX-G 5040Z body equipped with an AD-5040Lows and an AD-5040HS lens. Micro-wear analysis was performed using the mentioned Hirox microscope fitted out with a MXG-10C body and an OL-140II lens (140x-480x). The microscope enables us to obtain in-focused pictures through the overlapping of planes taken at different focus levels (Arrighi et al., 2016; Moretti et al., 2015).

The traces on the archaeological lithic tools were interpreted by means of the comparison with the experimental reference collection of the U.R. Preistoria e Antropologia - University of Siena, Italy.

\section{Results}

\subsection{Blank}

The majority of blanks (almost $50 \%$ of the complex) are of medium size (Table 1). Based on the elongation index, the main objects pursued were flakes (Table 2) and most of them could be considered as rectangular (with at least two cutting edges) (Table 3); 34 pieces have a backed side (Table 4).

Table 1. Size of target objects.

\begin{tabular}{lc}
\hline Size & $\mathbf{N}$. \\
\hline Big & 77 \\
Medium & 148 \\
Small & 87 \\
\hline Total & $\mathbf{3 1 2}$ \\
\hline
\end{tabular}


Table 2. Elongation index of target objects.

\begin{tabular}{lc}
\hline Elongation Index & $\mathbf{N}$. \\
\hline Blade & 52 \\
Long Flake & 71 \\
Flake & 189 \\
\hline Total & $\mathbf{3 1 2}$ \\
\hline
\end{tabular}

Table 3. Shape of target objects.

\begin{tabular}{lc}
\hline Shape & $\mathbf{N}$. \\
\hline Rectangular & 270 \\
Triangular & 42 \\
\hline Total & $\mathbf{3 1 2}$ \\
\hline
\end{tabular}

Table 4. Section of target objects.

\begin{tabular}{lc}
\hline Section & N. \\
\hline Trapezoidal $\backslash$ triangular & 278 \\
Rectangular trapeze or triangle & 34 \\
\hline Total & $\mathbf{3 1 2}$ \\
\hline
\end{tabular}

Combining these technical traits, we obtained the blanks on which the active and prehensile parts of the instrument are imposed (Figure 7). The majority of Oscurusciuto SU 13 target objectives of Levallois debitage are rectangular flakes of medium and small size, followed by rectangular big and medium long flakes and big blades. We note that elongated products are mostly big and medium sized, whereas flakes are mostly small. Convergent flakes are scarcely represented, no matter what the size. Except for convergent medium flakes (19 pieces), other sizes do not account for more than ten unities (Figure 7).

According to these characteristics, we can sub-divide the macro-class of blanks into: type-blank A, B or C. Type-blank A is made by rectangular blanks with one cutting edge opposed to a backed side. This group contains small, medium and big rectangular flakes, long flakes and blades with rectangular-trapeze and triangular-trapeze sections, which means one cutting edge opposed to a back (34 pieces). Type-blank B is made by the rectangular blanks with at least two cutting edges. This group comprehends small, medium and big rectangular flakes, long flakes and blades with trapezoidal and triangular sections, which means pieces with at least 2 cutting edges (233 pieces). Type-blank $\mathrm{C}$ is made by convergent blanks with at least two cutting edges. This group comprehends small, medium and big convergent flakes, long flakes and blades with trapezoidal and triangular sections, which means pieces with at least 2 cutting edges (42 pieces).

Having defined these three classes of blanks, in this paper, we decided to focus only of the type-blank A in order to give extensive attention to each category (further work will focus on the other two blank type, B and C) (Figure 7). 
a.

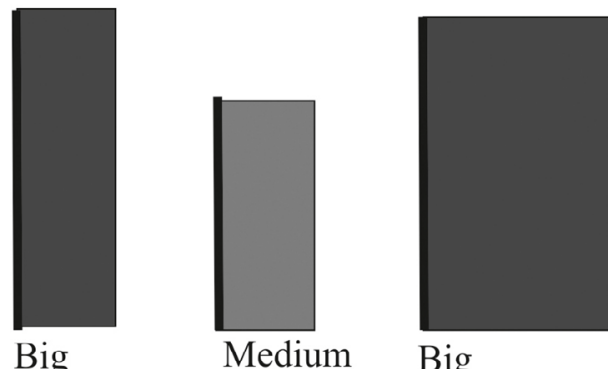

rectangular rectangular rectangular

blade

long flake

b.
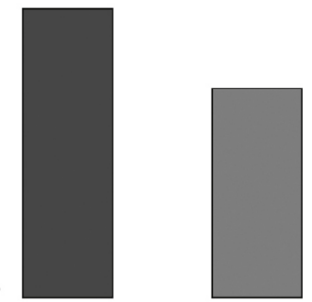

Big

Medium

rectangular rectangular

blade

blade

c.
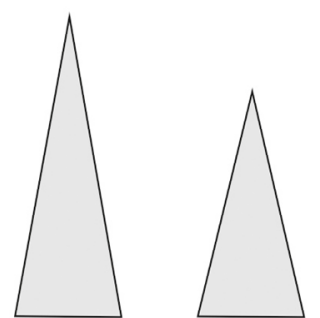

Big

Medium

blade

blade
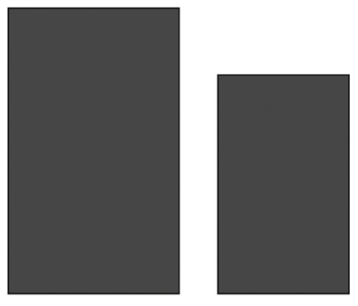

Big

Medium

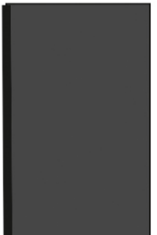

Medium

rectangular

long flake

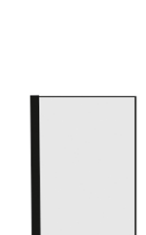

Small

rectangula long flake

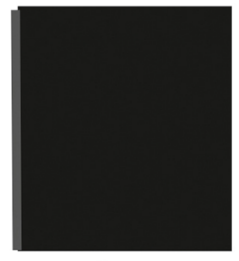

Medium

rectangular flake

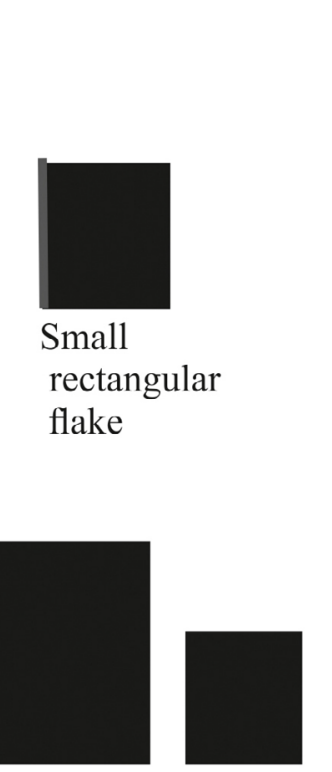

Medium

rectangular

flake

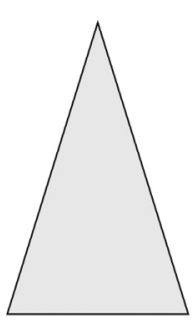

Big rectangular rectangular rectangular rectangular
long flake long flake long flake flake

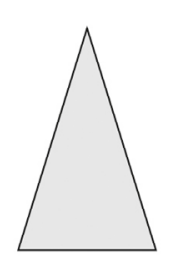

Medium

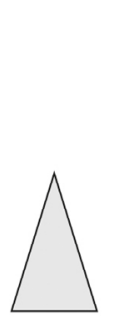

Small

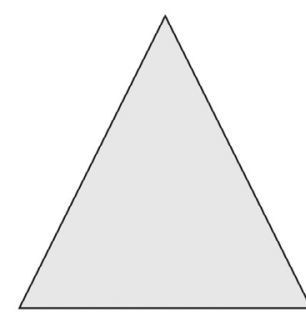

Big

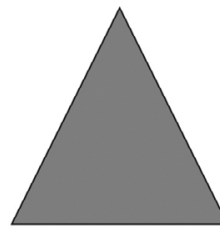

Medium

convergent convergent convergent

long flake long flake flake

long flake

$\begin{array}{ll}\text { convergent convergent } & \text { convergent } \\ \text { long flake flake } & \text { flake }\end{array}$

\section{SECTION}
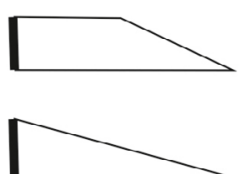

Triangular or

trapezoidal

1 sharp edge +1

back

\section{SECTION}

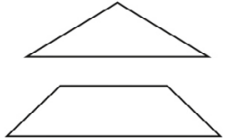

Triangular or

Small

rectang

trapezoidal

2 sharp edges
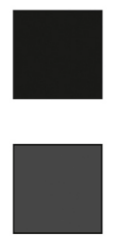

$21-30$

$11-20$

Figure 7. a. Type-blank A rectangular blanks with one cutting edge opposed to a backed side. b. Type-blank B: rectangular blanks with at least two cutting edge. c. Typeblank C: convergent blanks with at least two cutting edges (the scale of colour indicates the number of items: darker = more frequent and lighter $=$ less frequent). 


\subsection{Type-blank A}

Type-blank A encompassed 34 pieces, most of them are elongated supports (blades or long flakes) (Table 5).

Table 5. Type-blank A rectangular blanks with one cutting edge opposed to a backed side.

\begin{tabular}{lc}
\hline Blank & Quantity \\
\hline Big blade & 8 \\
Medium blade & 5 \\
Big long flake & 6 \\
Medium long flake & 2 \\
Small long flake & 1 \\
Medium flake & 9 \\
Small flake & 3 \\
\hline Total & $\mathbf{3 4}$ \\
\hline
\end{tabular}

On these supports several UTFt are imposed: 21 UTFt trihedrons (from now UTFt T or just T) and 39 UTFt cutting edges (from now UTFt C or just C) (Table 6).

Table 6. presence of UTFt and UTFp.

\begin{tabular}{llc}
\hline UTF types & Quantity \\
\hline UTFt & Rectilinear cutting edge & 30 \\
& Denticulate cutting edge & 5 \\
& Convex cutting edge & 3 \\
& Concave cutting edge & 1 \\
& Trihedron & 21 \\
\hline UTFp & 1 backed side & 2 \\
& 2 backed sides & 19 \\
& 3 backed sides & 13 \\
\hline
\end{tabular}

The most represented UTFt is the cutting edge. It could be found alone, in association with a trihedron, or with other cutting edges (Table 7). The majority of cutting edges show a rectilinear delineation, less represented are denticulate, convex and concave forms (Table 6). Usually cutting edges are in a lateral position (32) and occupy $3 \backslash 4$ or the totality of the edge of the tool.

The 21 UTFt trihedron are made up by 3 planes encompassing the dorsal and ventral faces of the flakes plus the butt, or plus a third face constituted by a rib made up of two negatives on the dorsal surface or by a broken portion of the flakes, which lets us suppose an intentional use of the fracture. Consequently, these UTFt are slightly difficult to identify, as their features, (when the rib or butt is the third face), mostly occur during the production of the pieces and not through intentional action (like in the case of intentional fracture). This issue could have caused an overestimation of this UTFt.

The UTFp are found in several different combinations: the most relevant one is the presence of 2 backed sides (most of them proximal plus lateral) and the 3 backed sides that actually forms a frame around the piece (from now on we refer to backed side with D) (Table 6, Table 7).

Going into more detail, we focused on the combination among the active parts (UTFt C and UTFt T), plus their association with the prehensile parts (UTFp). In this way we were 
able to individuate classes of tools that have the same structure (techno-type). For the nomenclature, we describe each tool based on the combination of UTFt and UTFp (UTFt cutting edge $=\mathrm{C}$, UTFt Trihedron $=\mathrm{T}$; UTFp backed side $=\mathrm{D}$ ), the repetition of each letter represents the frequency of the unity. The techno-type is indicated with a letter and the subtype is indicated by a number. It this way each piece is described by a code i.e. CDD-A1 means a piece with one UTFt cutting edge: $\mathrm{C}+$ two backed sides: DD, belonging to technotype A, subtype 1 .

Table 7. Techno-type and subtype defined by the combination of UTFt and UTFp. The column "plus UTF trihedron" indicates how many trihedrons are present on the pieces (please note that this column refers the number of UTFt Trihedrons and not to the number of pieces).

\begin{tabular}{lcc}
\hline Techno - Type and Sub-type & N. of Pieces & Plus UTFt trihedron \\
\hline A: 1 Cutting edge $+\mathbf{2}$ backed sides (CDD) & $\mathbf{1 3}$ & $\mathbf{3}$ \\
\hline A.1 Cutting edge with denticulate delineation & 3 & 1 \\
A.2 Cutting edge with rectilinear delineation & 6 & 2 \\
A.3 Cutting edge with transversal position (rectilinear) & 1 & 0 \\
A.4 Cutting edge with convex delineation & 2 & 0 \\
A.5 Cutting edge with concave delineation & 1 & 0 \\
\hline B: 1 Cutting edge + $\mathbf{1}$ backed side (CD) & $\mathbf{2}$ & $\mathbf{0}$ \\
\hline C: $\mathbf{2}$ Cutting edge $+\mathbf{2}$ backed sides (CCDD) & $\mathbf{6}$ & $\mathbf{3}$ \\
\hline C.1 Contiguous cutting edges & 4 & 1 \\
C.2 Separated cutting edges & $\mathbf{2}$ & 2 \\
\hline D: 1 Cutting edge $+\mathbf{3}$ backed sides (CDDD) & $\mathbf{1 2}$ & $\mathbf{1 2}$ \\
\hline D.1 Cutting edge with denticulate delineation & 2 & 1 \\
D.2 Cutting edge with rectilinear delineation & 9 & 9 \\
D.3 Cutting edge with convex delineation & 1 & 2 \\
\hline E: 1 Trihedron $+\mathbf{3}$ backed sides (TDDD) & $\mathbf{1}$ & $\mathbf{1}$ \\
\hline
\end{tabular}

We recognized 5 techno-types, presenting a variety of sub-types (Figure 8, Table 7). To sum up the most common techno-type was A: 1 cutting edge +2 backed sides (CDD), present in sub-types 1, 2, 3, 4 and 5. Sub-types 1, 2, 4, and 5 have the cutting edge opposed to the lateral backed side, whereas sub-type 3 is the only one that has just one cutting edge in a transversal position (Figure 8, Table 7).

Highly represented is also techno-type D: 1 cutting edge +3 backed sides (CDDD), whose peculiarity the 3 backed sides constituting a frame for the cutting edge. Not surprisingly this is where we find the major number of trihedrons as the backed side is actually the third surface that enhanced the creation of the trihedron itself. The pieces of techno-type B: 1 cutting edge +1 backed side (CD), are peculiar because in both cases the UTFp is made through retouch. Finally, we have only one case of techno-type E: 1 trihedron +3 backed sides (TDDD). This piece is very interesting as it is the smallest tool in the collection; here the intention of creating 3 backed sides as prehensile portion leaving free only the distal trihedron become clear. This is also the only case were the trihedron is found alone and not connected with other UTFt (Figure 8, Table 7).

These above-mentioned techno-types and sub-types could be found imposed on various blanks. Starting from the blades, these pieces are found in big and medium sizes; generally, we noted a recurrence of 2 baked sides and an opposite cutting edge. Incidentally, each tool has its own peculiarities; they are supports for different sub-types (Table 8, Figures 8, 9, and 10). The case of the pieces ID 919 and ID 989 (techno-type B) is interesting because the retouch is implemented to improve the adherence potential of the grip, and it is adjacent to the cutting edge opposed to the backed side. This configuration of the tool introduces the hypothesis of a hafting (Figure 9). 
Techno-type A: CDD

!'
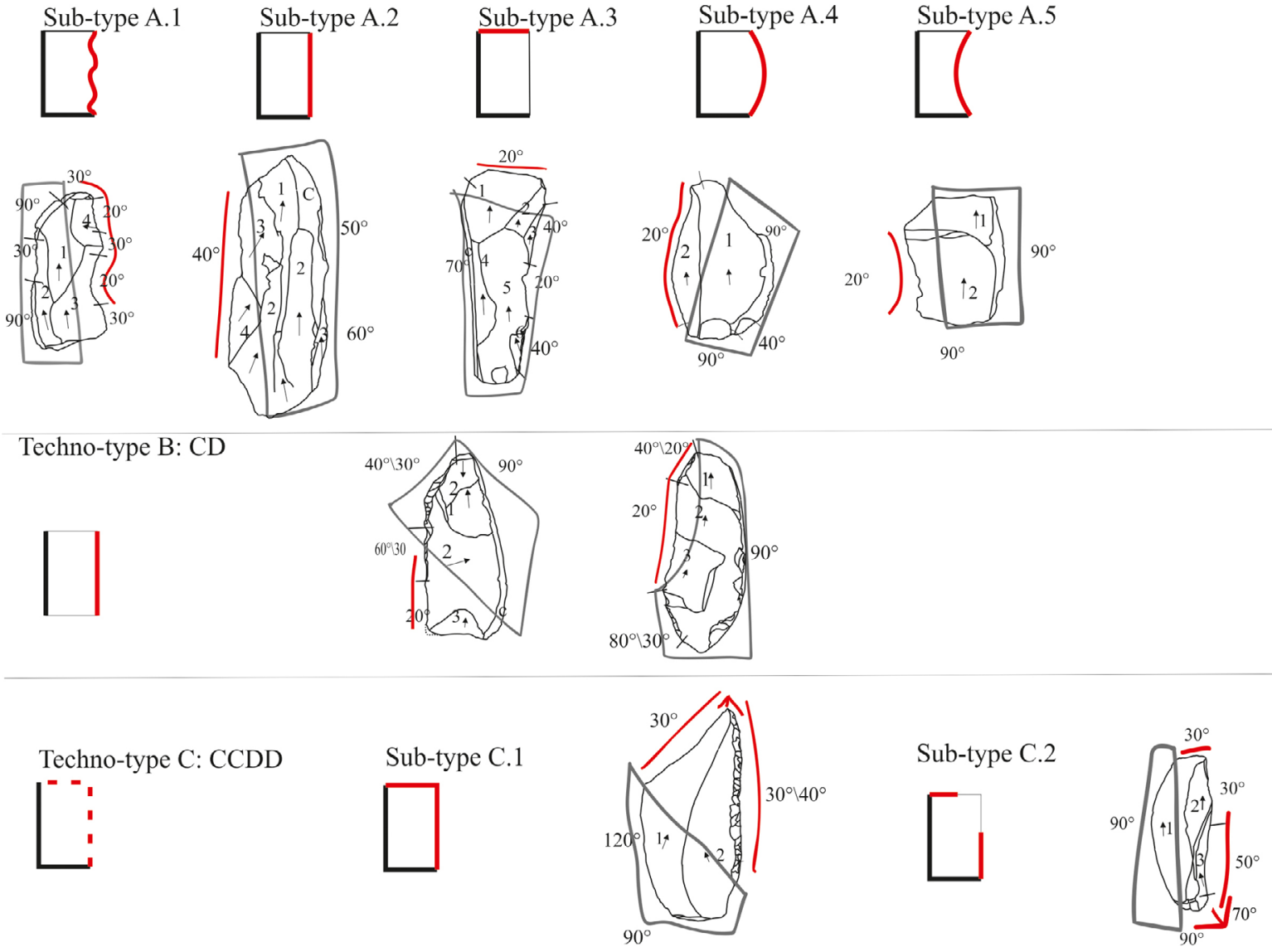

Techno-type D: CDDD

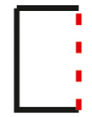

Sub-type D.1

Sub-type D.2

Sub-type D.3
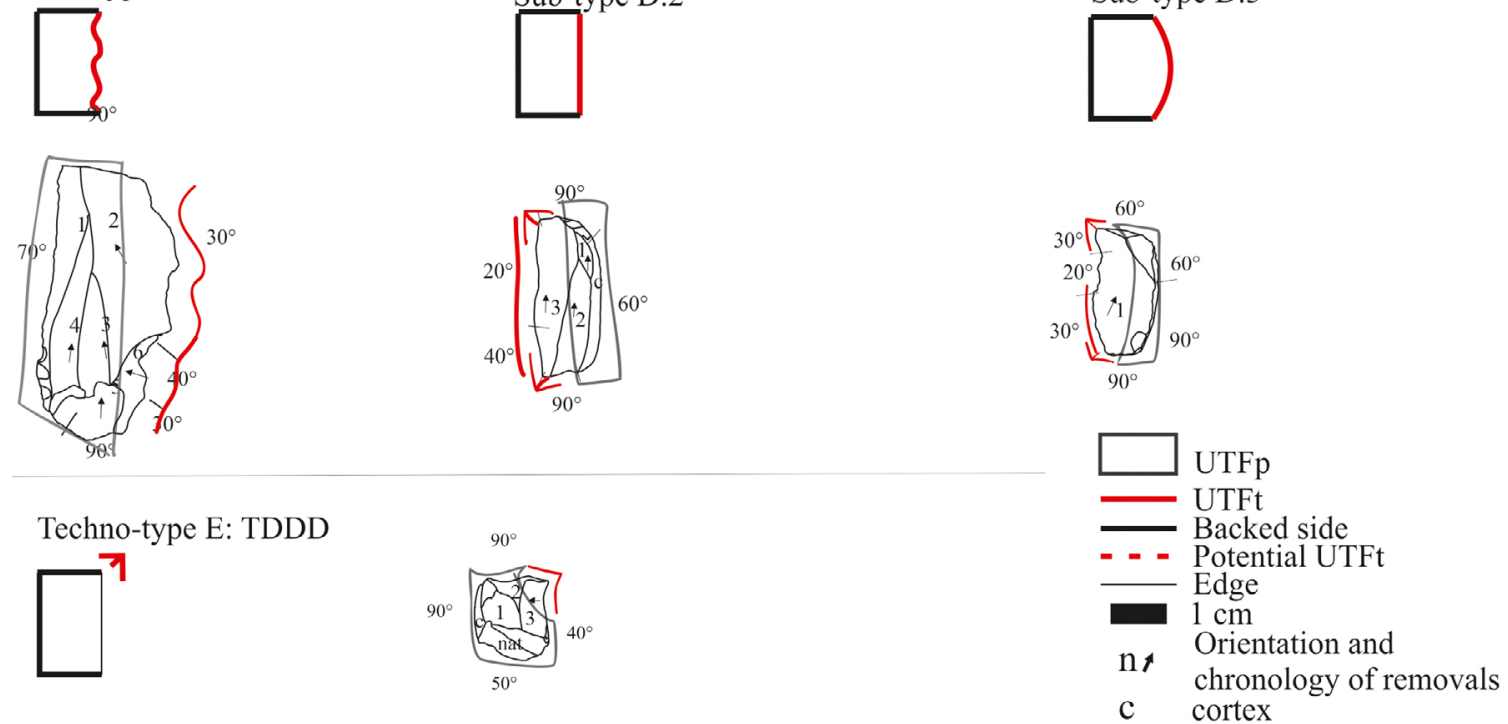

Figure 8. Schematic composition of techno-type and sub-type, plus examples of tools for each category. 
Table 8. Synthetic table of techno-types and sub-types (C: cutting edge, T: trihedron: D: backed side; n. refers to the total number of pieces of each type), how they are disposed on the blank, plus information regarding the use: action, worked material and angles of the active edge (for the blank: BB: big blade, MB: medium blade, BL: big long flake, ML: medium long flake, SL: small long flake, MF: medium flake, SF: small flake).

\begin{tabular}{|c|c|c|c|c|c|c|c|c|c|c|c|c|c|c|}
\hline \multirow{2}{*}{\multicolumn{2}{|c|}{ Techno-type }} & \multirow{2}{*}{$\begin{array}{l}\text { Sub- } \\
\text { type }\end{array}$} & \multirow[b]{2}{*}{$\mathbf{N}$. } & \multicolumn{7}{|c|}{ Blank } & \multirow[b]{2}{*}{ Action } & \multirow[b]{2}{*}{ Material } & \multirow[b]{2}{*}{ Angles } & \multirow[b]{2}{*}{ ID pezzi } \\
\hline & & & & BB & MB & BL & $\mathbf{M L}$ & SL & MF & SF & & & & \\
\hline & $A:$ & A.1 & 3 & 1 & & 1 & & & & 1 & cut & soft, hard & $20^{\circ}, 20^{\circ},-30^{\circ}$ & $28,894,214$ \\
\hline & \multirow[t]{4}{*}{$\mathrm{n} 13$} & A. 2 & 6 & 1 & & 1 & 1 & 1 & 2 & & cut & $\begin{array}{l}\text { semi-hard, } \\
\text { hard }\end{array}$ & $\begin{array}{l}20^{\circ}, 30^{\circ}, 20^{\circ},-30^{\circ}, \\
40^{\circ}\end{array}$ & $\begin{array}{l}983,47,318,1512,531, \\
906\end{array}$ \\
\hline & & A.3 & 1 & 1 & & & & & & & 1 & 1 & $20^{\circ}$ & 959 \\
\hline & & A.4 & 2 & & 1 & 1 & & & & & cut & soft & $20^{\circ}$ & 400,320 \\
\hline & & A.5 & 1 & & & & & & 1 & & cut & semi-hard, & $20^{\circ}$ & 82 \\
\hline & $\begin{array}{l}\text { B: } \\
\text { CD n.2 }\end{array}$ & $\mathrm{B}$ & 2 & 2 & & & & & & & $\begin{array}{l}\text { scrape, } \\
\text { cut }\end{array}$ & soft & $20^{\circ}$ & 919,989 \\
\hline \multirow[t]{2}{*}{} & $\begin{array}{l}\text { C: } \\
\text { CCDD }\end{array}$ & C.1 & 4 & 2 & & 1 & & & 1 & & $\begin{array}{l}\text { cut, } \\
\text { scrape }\end{array}$ & $\begin{array}{l}\text { semi-hard, } \\
\text { hard }\end{array}$ & $20^{\circ}, 30^{\circ}, 40^{\circ}$ & $633,1384,1632,846$ \\
\hline & n.6 & C. 2 & 2 & & 2 & & & & & & scrape & soft & $20^{\circ}, 30^{\circ}, 50^{\circ}$ & 852,853 \\
\hline \multirow{3}{*}{ 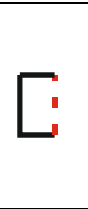 } & $\mathrm{D}:$ & D.1 & 2 & 1 & & & & & 1 & & cut, carve & soft & $20^{\circ}, 30^{\circ},-40^{\circ}$ & 213,991 \\
\hline & $\begin{array}{l}\text { CDDD } \\
\mathrm{n} .12\end{array}$ & D.2 & 9 & & 2 & 2 & & & 4 & 1 & $\begin{array}{l}\text { cut, } \\
\text { scrape }\end{array}$ & $\begin{array}{l}\text { semi-hard, } \\
\text { hard }\end{array}$ & $\begin{array}{l}20^{\circ},-40^{\circ}, 20^{\circ},-40^{\circ}, \\
30^{\circ}, 40^{\circ}, 50^{\circ}\end{array}$ & $\begin{array}{l}495,102,165,636,371, \\
712,632,1012,414\end{array}$ \\
\hline & & D. 3 & 1 & & & & 1 & & & & 1 & 1 & $30^{\circ}$ & 1628 \\
\hline \multirow[t]{2}{*}{$\square^{\top}$} & $\begin{array}{l}\text { E: TDDD } \\
\text { n.1 }\end{array}$ & $E$ & 1 & & & & & & & 1 & carve & hard & & 882 \\
\hline & & Total & 34 & 8 & 5 & 6 & 2 & 1 & 9 & 3 & & & 1 & 1 \\
\hline
\end{tabular}




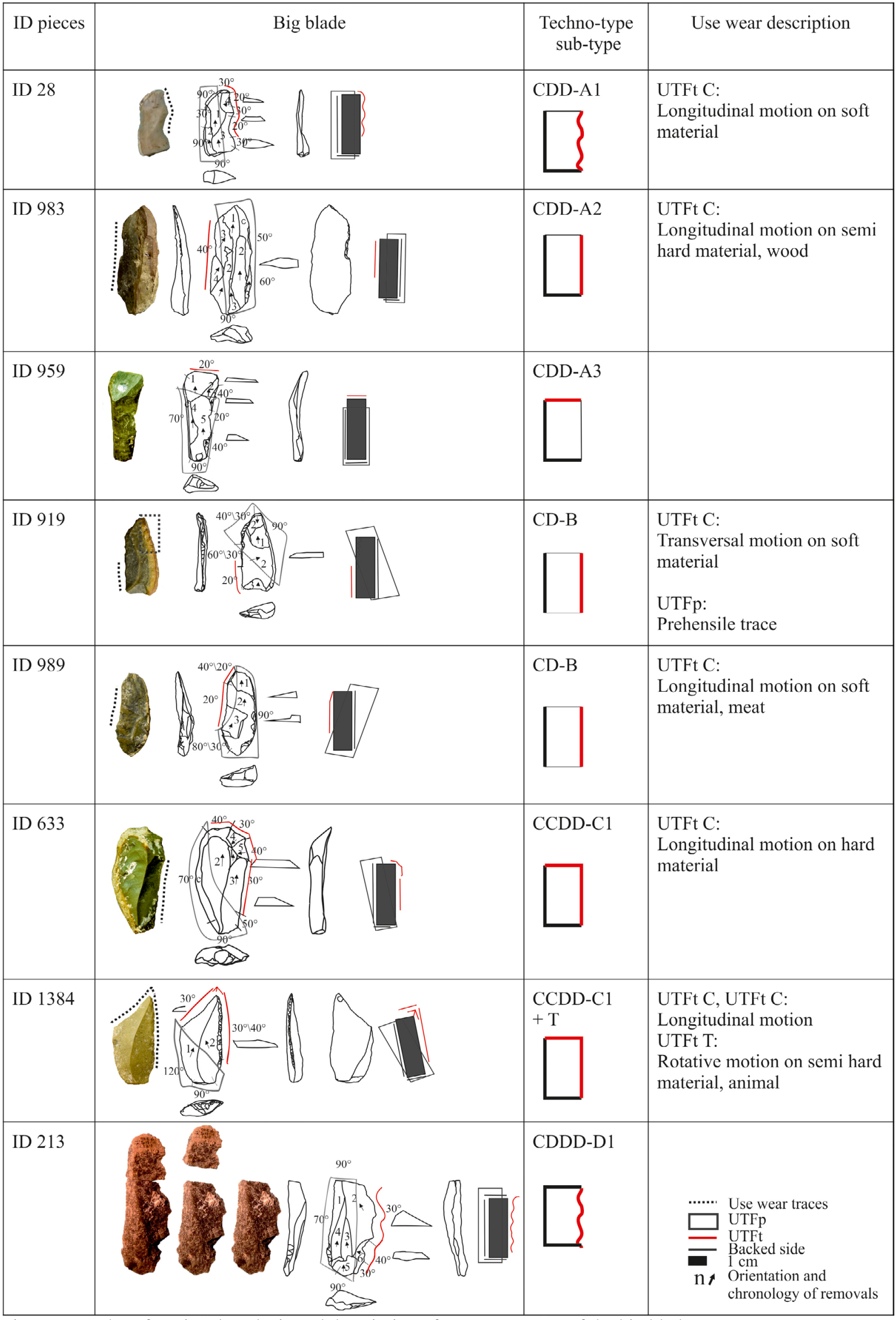

Figure 9. Techno-functional analysis and description of use wear traces of the big blades. 


\begin{tabular}{|c|c|c|c|}
\hline ID Pieces & Medium Blades & $\begin{array}{l}\text { Techno-type } \\
\text { sub- type }\end{array}$ & Use wear description \\
\hline ID 400 & 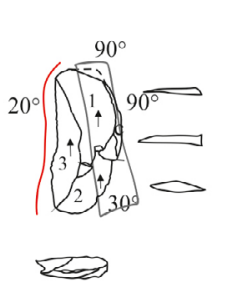 & CDD-A4 & $\begin{array}{l}\text { UTFt C: } \\
\text { Longitudinal motion on soft } \\
\text { material }\end{array}$ \\
\hline ID 495 & & $\begin{array}{l}\text { CDDD-D2 } \\
+\mathrm{T} \\
\square\end{array}$ & \\
\hline ID 1020 & $\begin{array}{l}1210 \\
<\infty\end{array}$ & $\begin{array}{l}\text { CDDD-D2 } \\
+\mathrm{T}+\mathrm{T} \\
\square\end{array}$ & $\begin{array}{l}\text { UTFt C: } \\
\text { Longitudinal motion on hard } \\
\text { material } \\
\text { UTFp: } \\
\text { Prehensile trace }\end{array}$ \\
\hline ID 852 & & $\begin{array}{l}\text { CCDD-C2 } \\
+\mathrm{T} \\
\square \\
\square\end{array}$ & $\begin{array}{l}\text { UTFt C: } \\
\text { Transversal motion on soft } \\
\text { material, wood }\end{array}$ \\
\hline ID 853 & $\mathbb{R}$ & $\begin{array}{l}\text { CCDD-C2 } \\
+\mathrm{T} \\
\square\end{array}$ & 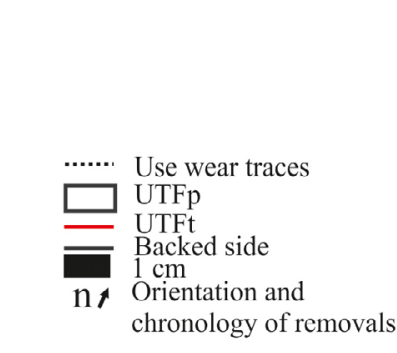 \\
\hline
\end{tabular}

Figure 10. techno-functional analysis and description of use wear traces of the medium blades.

Considering the medium blades, the pieces ID 852 and ID 853 refits, in this case it is interesting that the same configuration of the tool is created in the same core. Namely, pieces that technologically play the role of predetermining-predetermined pieces from a technofunctional point of view present identical the same prehensile and active portions (sub-type C2) (Table 8, Figures 8 and 10).

As for the long flakes, we encountered specimens of every sizes: big, medium, and small in varying numbers (Figures 11 and 12). This is the blank with the most variations in technotypes, in fact of 9 pieces we noted 8 different sub-types (Table 8, Figures 8, 11, and 12). 


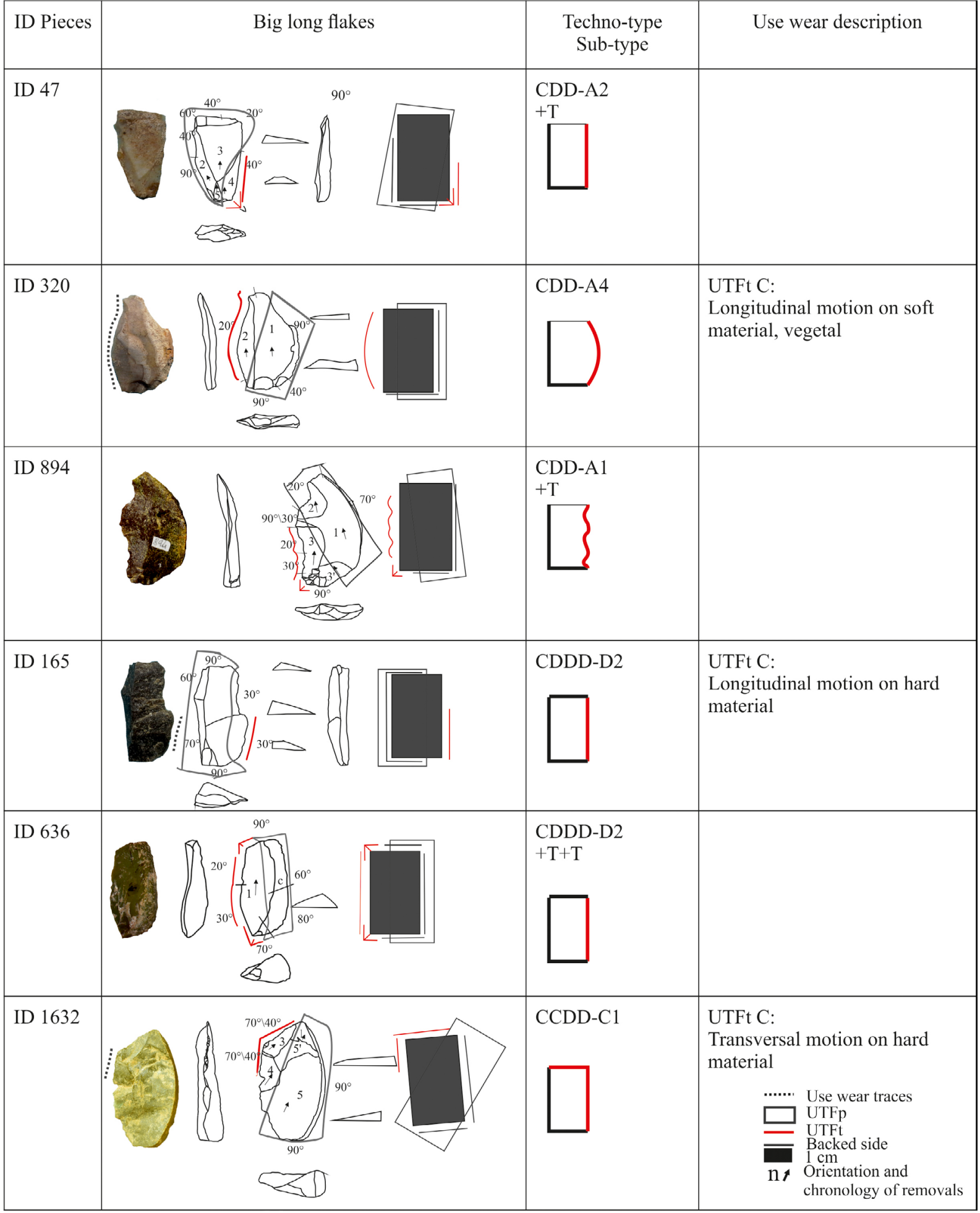

Figure 11. Techno-functional analysis and description of use wear traces of the big long flakes.

Flakes are represented only in small and medium sizes (Figures 13 and 14). The main defining feature in these pieces is the presence of 3 framed backed sides (techno-type D) (Table 8, Figures 8 and 13). Probably because of their small dimensions, these small pieces, show a particular prehensile need that could be met by the 3 backed sides, artifice that permit the creation of trihedrons. 


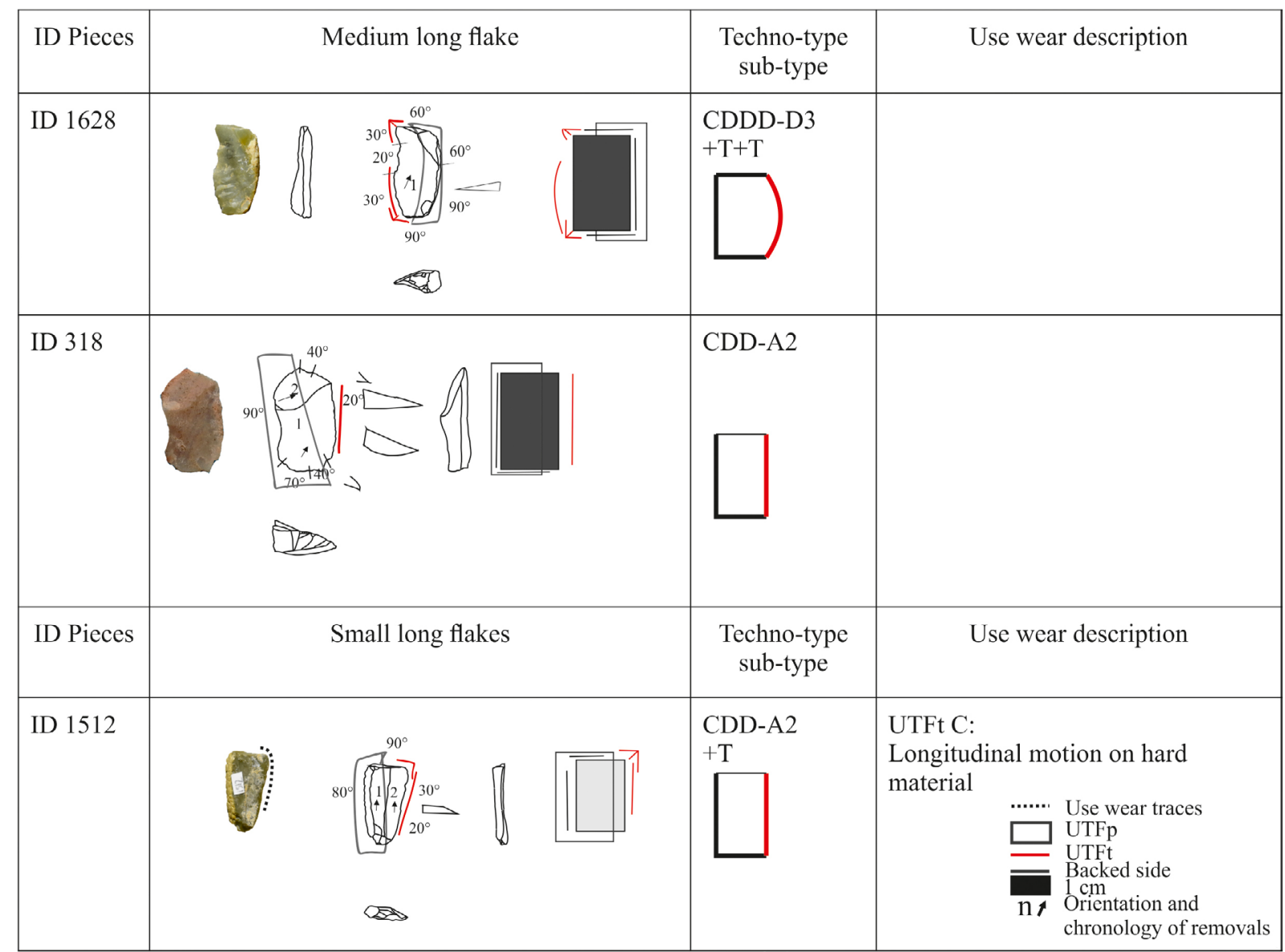

Figure 12. Techno-functional analysis and description of use wear traces of the medium long flakes and small long flakes.

\subsection{Use-wear analysis}

Of the examined sample (34), 21 tools show evidence of use, 9 pieces display unclear or uncertain traces because of post-depositional modifications, 4 artefacts do not reveal use-wear at all. We noted that in the majority of the cases use-wear traces were found on the portion of the pieces recognized as active by the techno-functional analysis. Only in one case traces were found on another edge which was not recognized by techno-functional analysis (ID 991, Figure 13). In other cases, there was not enough microscopic evidence to prove the technofunctional reading.

Going more into detail, 22 UTFt were used, in particular we noted 20 cutting edges (UTFt C) and 2 trihedrons (UTFt T). In addition, traces were visible on 2 prehensile portions (UTFp). Each artefact showed evident traces on only one UTFt, with the exception of the piece ID 1384 where its 3 UTFt showed traces (Figure 15).

Due to the fact that micro-wear traces (polishes) are by nature not very evident, for several pieces it was inferred only the action carried out and general information about the hardness of the worked material. Nevertheless, as a general functional scene, we may deduce that techno-type analysed was regularly used for various tasks (Tables 8 and 9). The tools were used for processing hard (9), semi-hard (8) and soft materials (5). Such a variety is confirmed also when worked materials have been detected, as both vegetal (4) and animal tissues (4) were processed (Table 9, Figure 16). 


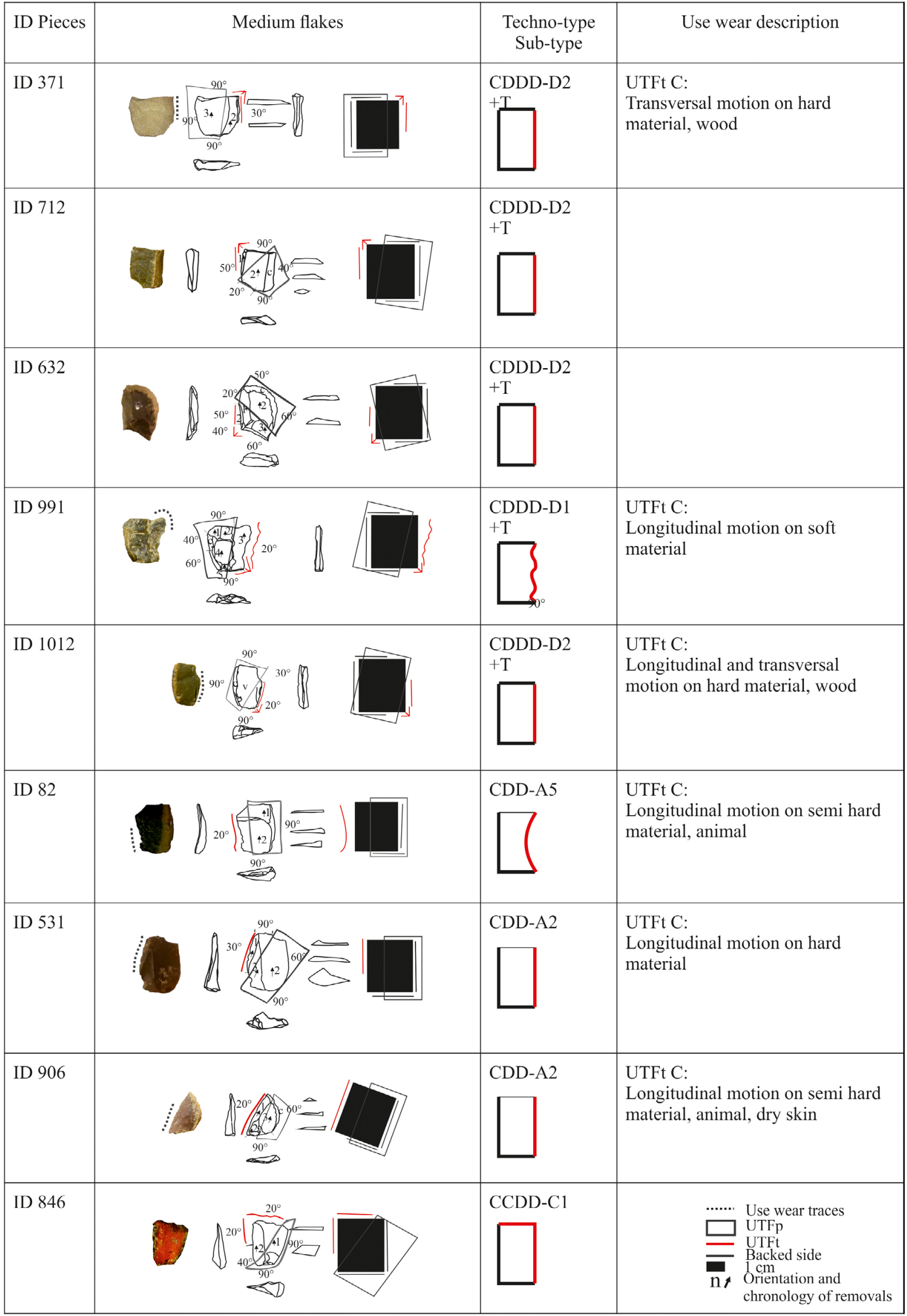

Figure 13. Techno-functional analysis and description of use wear traces of the medium flakes. 


\begin{tabular}{|c|c|c|c|}
\hline ID Pieces & Small flakes & $\begin{array}{l}\text { Techno-type } \\
\text { sub-type }\end{array}$ & Use wear description \\
\hline ID 214 & $90^{\circ}$ & $\begin{array}{l}\text { CDD-A1 } \\
+\mathrm{T} \\
\square ?\end{array}$ & $\begin{array}{l}\text { UTFt C: } \\
\text { Longitudinal motion on hard } \\
\text { material }\end{array}$ \\
\hline ID 414 & & $\begin{array}{l}\text { CDDD-D2 } \\
+\mathrm{T}\end{array}$ & \\
\hline ID 882 & *3) & TDDD-E & 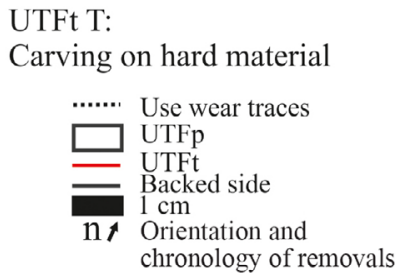 \\
\hline
\end{tabular}

Figure 14. Techno-functional analysis and description of use wear traces of the small flakes.

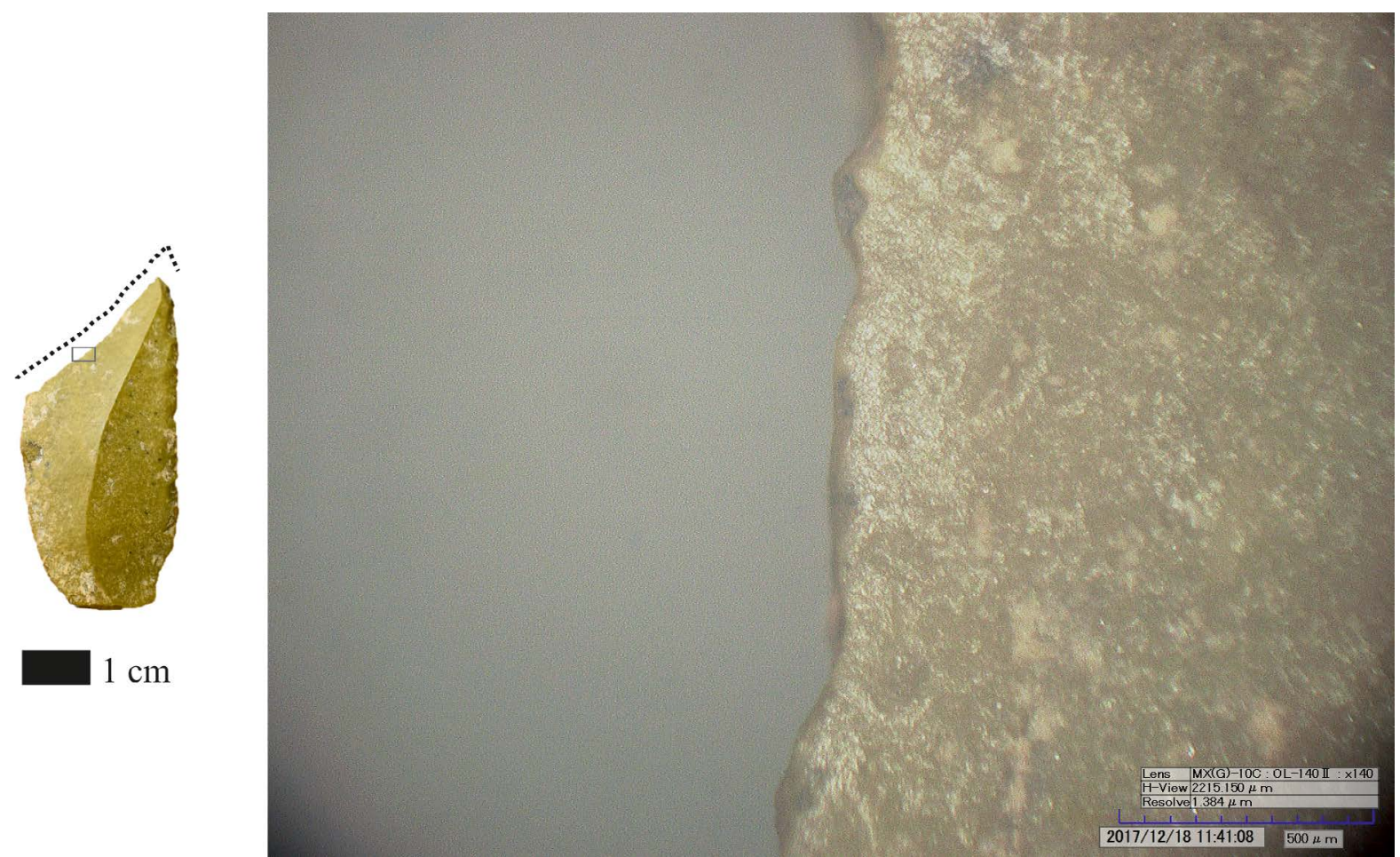

Figure 15. Use-wear polish on the big blade ID 1384 (the scale bar is $500 \mu \mathrm{m}$.). 
Table 9. Correlation among active parts (UTFt C: cutting edge and UTFt T: trihedron), movement and worked material.

\begin{tabular}{|c|c|c|c|c|c|c|c|c|c|}
\hline \multirow[t]{3}{*}{$\begin{array}{l}\text { Type of material } \\
\text { and UTF }\end{array}$} & \multicolumn{2}{|c|}{$\begin{array}{l}\text { Longitudinal } \\
\text { motion }\end{array}$} & \multicolumn{2}{|c|}{$\begin{array}{l}\text { Transversal } \\
\text { motion }\end{array}$} & \multicolumn{2}{|c|}{$\begin{array}{l}\text { Rotational } \\
\text { motion }\end{array}$} & \multicolumn{2}{|c|}{$\begin{array}{l}\text { Long+trans } \\
\text { motion }\end{array}$} & \multirow[t]{3}{*}{ Total } \\
\hline & UTFt & UTFt & UTFt & UTFt & UTFt & UTFt & UTFt & UTFt & \\
\hline & $\mathrm{C}$ & $\mathrm{T}$ & C & $\mathrm{T}$ & C & $\mathrm{T}$ & $C$ & $T$ & \\
\hline Soft & 2 & & 1 & & & & & & 3 \\
\hline Semi-hard & 5 & & & & & & & & 5 \\
\hline Hard & 3 & 1 & 2 & & & & & & 6 \\
\hline Wood & 1 & & 1 & & & & 1 & & 3 \\
\hline $\begin{array}{l}\text { Herbaceous } \\
\text { plants }\end{array}$ & 1 & & & & & & & & 1 \\
\hline $\begin{array}{l}\text { Soft animal } \\
\text { tissues }\end{array}$ & 1 & & & & & & & & 1 \\
\hline $\begin{array}{l}\text { Semi-hard animal } \\
\text { tissues }\end{array}$ & 2 & & & & & 1 & & & 3 \\
\hline Total & 15 & 1 & 4 & & 0 & 1 & 1 & 0 & 22 \\
\hline
\end{tabular}

UTFt C are used mainly for longitudinal actions and to a lesser extent in transversal movements. The transversal actions are carried out by cutting edges with wider angles, in particular when hard materials were processed. Comparing worked materials and motions, we may conclude that the transversal actions were mostly performed on hard material, while the longitudinal ones on all types of material (Tables 8 and 9, Figures 9 to 14 and 16).

Few items are employed in mixed actions. A single UTFt C, of the flake ID 1012, was used with both longitudinal and transversal movements for processing vegetal material (Figure 13, Tables 8 and 9). Whereas two different UTFt C of the big blade ID 1384 were both used for longitudinal actions and UTFt $\mathrm{T}$ was employed in a rotational motion. In both cases animal tissue was processed (Figure 15, Tables 8 and 9).

By means of a techno-functional analysis, 21 trihedrons were identified, but traces were found on only two UTFt T of which one was involved in a rotational motion (pieces ID 1384 Figure 15), and the other in a longitudinal action (pieces ID 882 - Figure 17) (Tables 8 and 9). These tools were used for processing hard and semi-hard material.

Evidence of probable hafting traces on UTFp is detected on two pieces (ID 1020 and ID 919), confirming the hypothesis of the techno-functional analysis. In both cases, the traces are located on the backed sides of the tools (Figures 9 and 10). In both cases, the traces are few bright spots located on the backed sides of the tools.

\section{Combined use of techno-functional and use-wear analysis}

The result obtained by the combined use of the techno-functional and use-wear analysis gives a consistent result. In fact, in the sampled pieces, we note that in the majority of the pieces the use-wear analysis confirmed the interpretation given in the techno-functional study.

We note that sometimes the same techno-type are installed on different blanks, as in the case of sub-type A2 and D2, a recurrent combination in almost all blanks. Then again, other techno-types seem to be specific to some blanks, such as techno-type B. Moreover, some blanks are the support for several techno-types, e.g., the big blades present quite a number of different combinations, and they seem to be made to purpose unique tools. In contrast, other blanks support few techno-types, as is the case with medium flakes where most of them support the techno-type D (Table 8). 
A

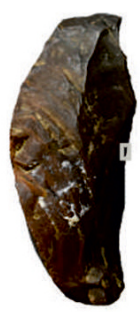

\section{$1 \mathrm{~cm}$}

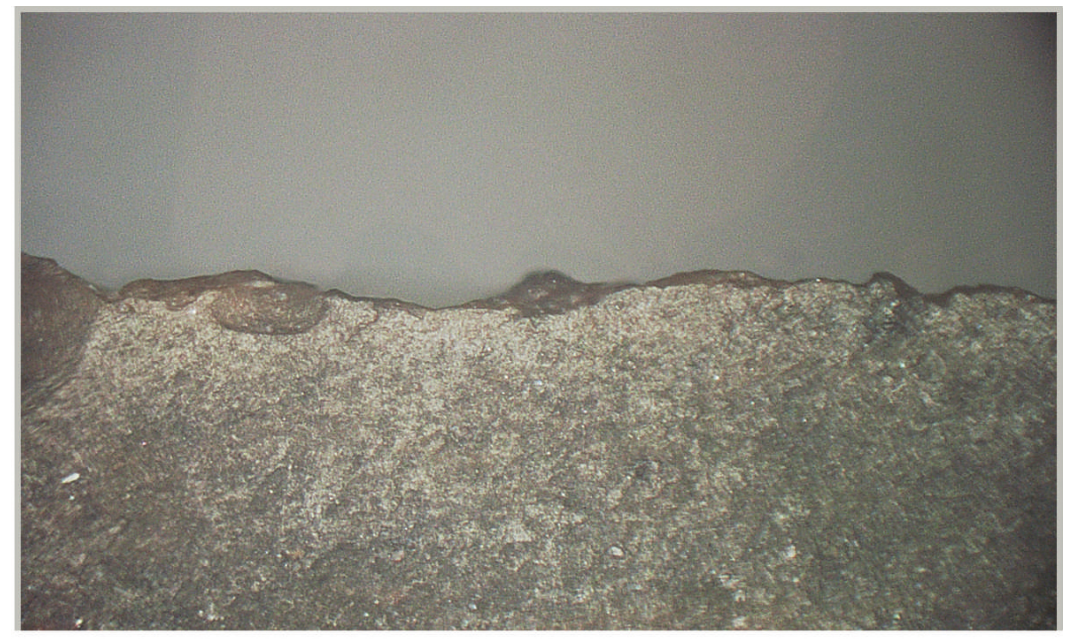

B

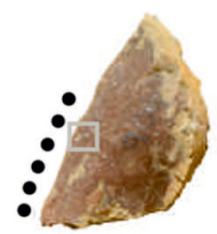

\section{$1 \mathrm{~cm}$}
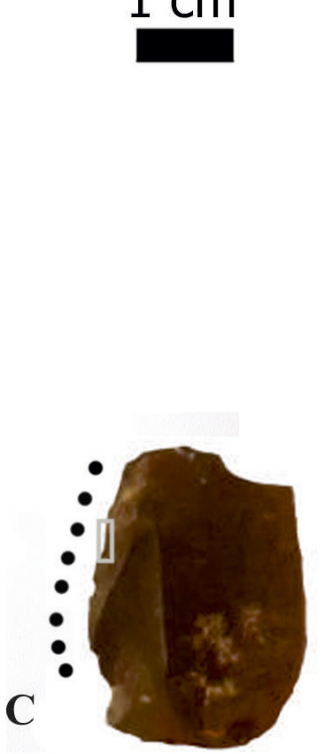

$1 \mathrm{~cm}$
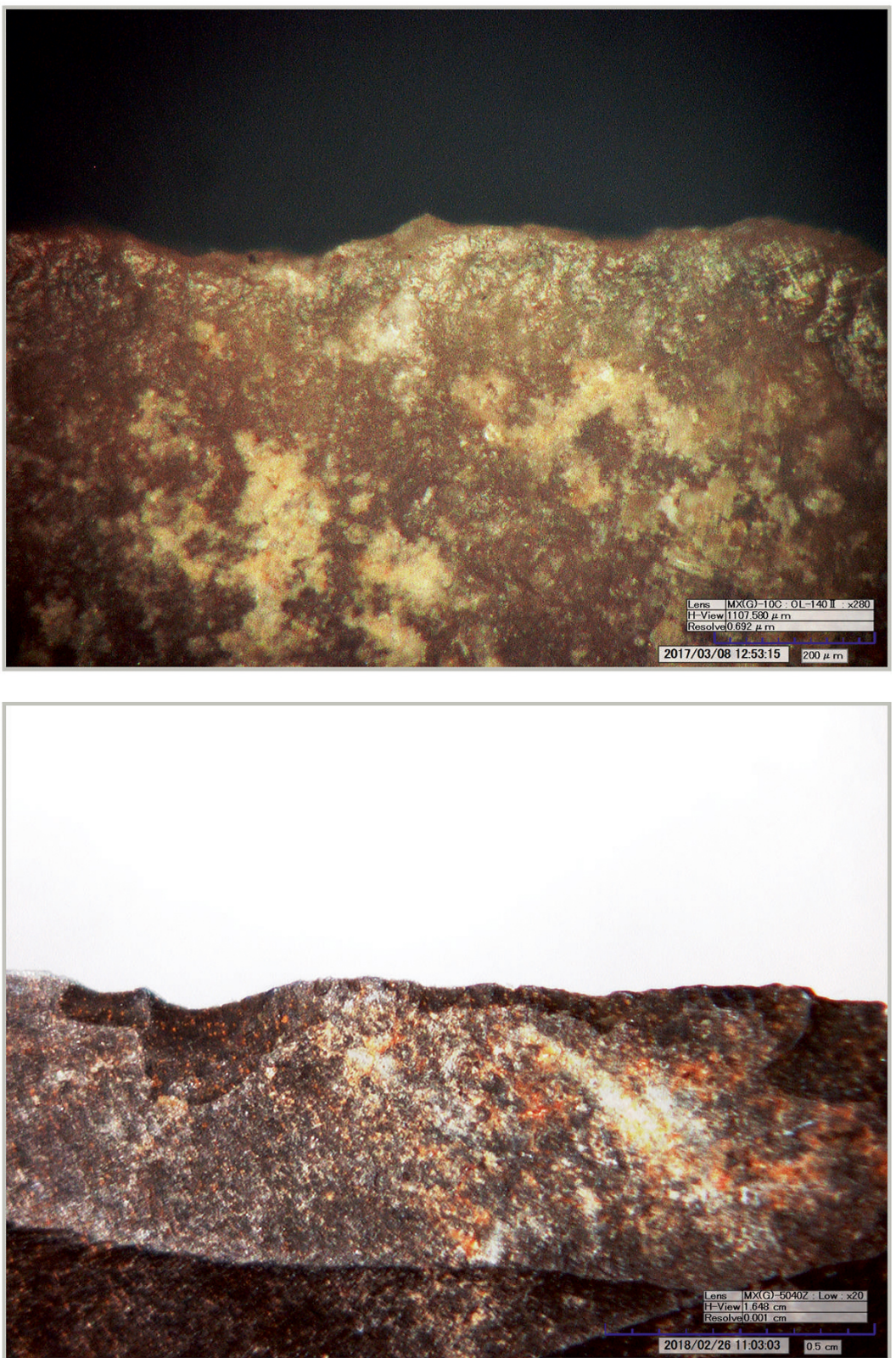

Figure 16. A. ID 852 - use-wear polish interpreted as due to processing soft wood (the scale bar is $500 \mu \mathrm{m}$ ); B. ID 906 - edge rounding associated with use-wear polish from cutting dry skin (the scale bar is $200 \mu \mathrm{m}$ ); C. ID 531 - edge scarring related to cutting hard material (the scale bar is $0.5 \mathrm{~cm}$ ). 

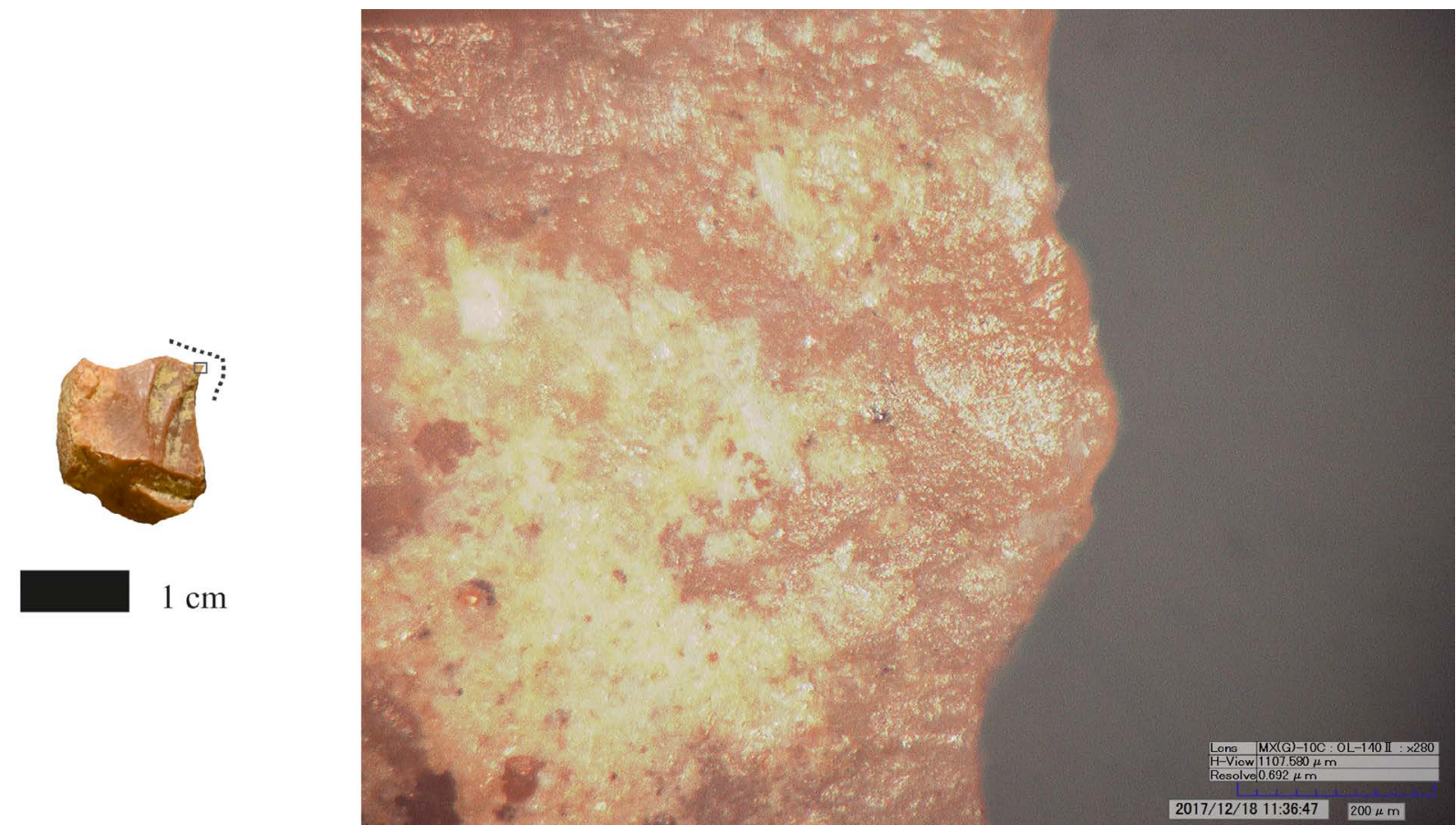

Figure 17. Use-wear polish associated with edge rounding of the small flake ID 882 (the scale bar is $200 \mu \mathrm{m}$ ).

A very remarkable fact is that the techno-types are consistent with their actual use, in fact we noted that some techno-types were used for specific activities, as is the case with technotype A, which is mostly used for cutting (longitudinal movement). On the other hand, there are techno-types, such as $\mathrm{C}$ and $\mathrm{D}$, which are employed in a variety of activities, such as cutting and scraping (respectively longitudinal and transversal movements). In addition, some techno-types met a particular need, as is the case with techno-type E, which can be considered unicum in the collection both from a structural and a functional point of view, in fact this piece (a UTFt T framed by 3 backed sides) was used for carving (Figure 17). Finally, in techno-type B a very specific construction of the piece (also produced by retouch) does not correspond the same activity, one is used for scraping and the other for cutting, however both pieces are related to butchering activities (Table 8).

\section{Conclusions}

A first methodological observation was that the integrated use of techno-functional analysis and use-wear analysis yields consistently matching results to the benefit of both technologists and tracceologists. Thanks to this combined method we get much closer to the human realities where there were several needs to solve, and several tools to be manufactured.

This work answered the three main queries posed at the beginning of this research.

1. We proved that the target objects (production-aims) were also actually used as functional objects (functional-aims), i.e. a large number of items shows use-wear.

2. We noted that each production-aim actually comprised several techno-types employed for different purposes. Namely, through the technological approach we learned that the production-aims was flakes, convergent flakes and backed flakes. Thanks to this study, we perceive great diversity in both structure and functionality of these tools, noting that to each class of target objects corresponds a set of different functional objects, as each category actually comprises several blanks, and each blank could be the support for several techno-types.

3. Finally, we also proved that tools with a specific structure aimed to solve a specific task. 
The encouraging results of this study motivated us to continue in this direction, analysing the other two categories (type-blanks B and C) in order to obtain a larger set of statistically significant data.

Lastly, one question remains: the trihedron was identified by techno-functional analysis but presented traces in only 2 cases. For this reason, we want to know why there is such little evidence of usage on these pieces. Is it because the action did not leave strong visible traces, or because this part was not used? We could also hypothesise an artificial increase due to possibly misleading criteria of identification. To be able to answer these questions we are planning to set up an experimental protocol to verify the functional potential or the trihedron, possibly applying more restrictive criteria for its identification, based on the technical criteria present on the two items which showed clear use-wear traces.

\section{Acknowledgements}

The authors are indebted to the Soprintendenza Archeologia, Belle Arti e Paesaggio per le province di Brindisi, Lecce e Taranto, Municipality of Ginosa, Onlus CESQ, to Piero di Canio and to all the students and colleagues who participated, together with the authors, in the excavation of 2011. This paper was presented at 11th International Symposium on Knappable Materials held in University of Buenos Aires between 7 and 12 November 2017. We would like to warmly acknowledge Roxane Rocca, Marcos César Pereira Santos, Birgitte Hoiberg Nielsen and the two reviewers Antonella Pedergnana and Amelie Da Costa for their precious and helpful advice. We thank also the session organizers Leslye Valenzuela, Otis Crandell, and Patrick Julig.

\section{Author contributions}

Giulia Marciani performed the technological and techno-functional analysis supervised by Daniele Aureli. Simona Arrighi performed the use-wear analysis. Vincenzo Spagnolo is responsible for the planimetries and spatial data. Paolo Boscato analyzed the faunal remains, and is the director of the excavation together with Annamaria Ronchitelli.

\section{References}

Abruzzese, C., Aureli, D. \& Rocca, R. 2016, Assessment of the Acheulean in Southern Italy: New study on the Atella site (Basilicata, Italy). Quaternary International, 393: 158-168. doi:10.1016/j.quaint.2015.06.005

Allen, J.R.M.M., Watts, W.A. \& Huntley, B. 2000, Weichselian palynostratigraphy, palaeovegetation and palaeoenvironment; the record from Lago Grande di Monticchio, southern Italy. Quaternary International, 73-74: 91-110. doi:10.1016/s10406182(00)00067-7

Arrighi, S., Bazzanella, M., Boschin, F. \& Wierer, U. 2016, How to make and use a bone "spatula”. An experimental program based on the Mesolithic osseous assemblage of Galgenbühel/Dos de la Forca (Salurn/Salorno, BZ, Italy). Quaternary International, 423: 143-165. doi:10.1016/j.quaint.2015.11.114

Aureli, D., Contardi, A., Giaccio, B., Jicha, B., Lemorini, C., Madonna, S., Magri, D., Marano, F., Milli, S., Modesti, V., Palombo, M.R. \& Rocca, R. 2015, Palaeoloxodon and human interaction: Depositional setting, chronology and archaeology at the Middle Pleistocene Ficoncella site (Tarquinia, Italy). PLoS One, 10(4): e0124498 (27 p.). doi:10.1371/journal.pone.0124498 
Aureli, D., Rocca, R., Lemorini, C., Modesti, V., Scaramucci, S., Milli, S., Giaccio, B., Marano, F., Palombo, M.R. \& Contardi, A. 2016, Mode 1 or mode 2? "Small tools” in the technical variability of the European Lower Palaeolithic: The site of Ficoncella (Tarquinia, Lazio, central Italy). Quaternary International, 393: 169-184. doi:10.1016/j.quaint.2015.07.055

Baena Preysler, J., Torres Navas, C., Pérez Díaz, S., Bustos-Pérez, G. \& Romagnoli, F. 2016, To grip or not to grip: an experimental approach for understanding the use of prehensile areas in Mousterian tools. Boletín de Arqueología Experimental, 11: 200-218. doi:10.15366/baexuam2016.11

Boëda, E. 1992, Approche de la variabilité des systèmes de production lithique des industries du Paléolithique inférieur et moyen : Chronologie d'une variabilité attendue. Technique et Culture, 17-18: 37-79. (in French) ("Approach to the variability of the lithic production systems of the Lower and Middle Palaeolithic industries: Chronology of an expected variability”) doi:10.4000/tc.685

Boëda, E. 1993, Le débitage discoïde et le débitage Levallois récurrent centripède. Bulletin de la Société préhistorique française, 90(6): 392-404. (in French) ("Discoid debitage and recurrent centripetal Levallois debitage”) doi:10.3406/bspf.1993.9669

Boëda, E. 1994, Le concept Levallois: Variabilité des méthodes (1st ed.). Monographie du CRA Vol. 9. Centre National de la Recherche Scientifique (CNRS), Paris, 280 p. (in French) ("The Levallois concept: Variability of methods")

Boëda, E. 1995, Levallois: A volumetric construction, methods, a technique. In: The definition and interpretation of Levallois technology (Dibble, H.L. \& Bar-Yosef, O., Eds.), Monographs in World Archaeology Vol. 23, Prehistory Press, Madison: p. 41-68.

Boëda, E. 1997, Technogenèse de systèmes de production lithique au Paléolithique inférieur et moyen en Europe occidentale et au Proche-Orient. Habilitation à diriger des recherches thesis at Université Paris X-Nanterre, Nanterre, 2 Vol., 173 p., 86 p. p. (in French) ("Technogenesis of Lower and Middle Palaeolithic lithic production systems in western Europe and the Near East”)

Boëda, E. 2001, Determination des unites techno-fonctionnelles de pieces bifaciales provenant de la couche acheuleenne C'3 base du site de Barbas I. In: Les industries à outils bifaciaux du Paléolithique moyen d'Europe occidentale, Actes de la table ronde organisée à Caen (Basse-Normandie - France), 14 et 15 octobre 1999 (Cliquet, D., Ed.), Université de Liège, Liège: p. 51-75. (in French) ("Determination of the technofunctional units of bifacial pieces from the $\mathrm{C} 3$ base acheuleenne base of the Barbas I site”)

Boëda, E. 2013, Techno-logique \& technologie: Une paléo-histoire des objets lithiques tranchants. Archéo-éditions, Prigonrieux, 266 p. (in French) ("Techno-logic \& technology: A paleo-history of sharp lithic objects”)

Boëda, E., Bonilauri, S., Kaltnecker, E., Valladas, H. \& Al-Sakhel, H. 2015, Un débitage lamellaire au Proche-Orient vers 40000 ans cal BP : Le site d’Umm el Tlel, Syrie centrale. Anthropologie (France), 119(2): 141-169. (in French) (“A bladelet production to the Near-East about 40000 (cal BP) years ago: The site of Umm el Tlel, central Syria”) doi:10.1016/j.anthro.2015.04.001

Bonilauri, S. 2010, Les outils du Paléolithique moyen : une mémoire technique oubliée ? Approche techno-fonctionnelle appliquée à un assemblage lithique de conception 
Levallois provenant du site d'Umm el Tlel (Syrie centrale). Doctorat en Préhistoire thesis at the École doctorale Milieux, cultures et sociétés du passé et du présent (Nanterre), Université Paris X- Nanterre, Nanterre, 469 p. (in French) ("Middle Palaeolithic tools: A forgotten technical memory? Techno-functional approach applied to a lithic assemblage of Levallois design from the site of Umm el Tlel (Central Syria)”) URL: http://www.theses.fr/2010PA100183

Boscato, P. 2017, Ambienti ed economia nel Paleolitico medio della Puglia: lo studio delle faune. In: Preistoria e Protostoria della Puglia. Atti della XLVII Riunione Scientifica IIPP, Ostuni (BR), 9-13 ottobre 2012 (Radina, F., Ed.), Studi di Preistoria e Protostoria Vol. 4, Istituto Italiano di Preistoria e Protostoria, Florence: p. 119-124. (in Italian) ("Environments and economy in the Middle Paleolithic of Puglia: The study of faunas")

Boscato, P. \& Crezzini, J. 2012, Middle-Upper Palaeolithic transition in Southern Italy: Uluzzian macromammals from Grotta del Cavallo (Apulia). Quaternary International, 252: 90-98. doi:10.1016/j.quaint.2011.03.028

Boscato, P., Gambassini, P., Ranaldo, F. \& Ronchitelli, A. 2011, Management of Palaeoenvironmental Resources and Exploitation of Raw Materials at the Middle Paleolithic site of Oscurusciuto (Ginosa, Southern Italy): Units 1 and 4. In: Neanderthal Lifeways, Subsistence and Technology (Conard, N.J. \& Richter, J., Eds.), Springer, Dordrecht: p. 87-98. doi:10.1007/978-94-007-0415-2_9

Brantingham, P.J. \& Kuhn, S.L.S.L.S.L. 2001, Constraints on Levallois Core Technology: A Mathematical Model. Journal of Archaeological Science, 28(7): 747-761. doi:10.1006/jasc.2000.0594

Da Costa, A. 2017, Rupture technique et dynamiques d'ocupation au cours de l'Holocène moyen au Brésil. Doctorate thesis at the École doctorale Milieux, cultures et sociétés du passé et du présent (Nanterre), Université Paris X- Nanterre, Nanterre, 406 p. (in French) ("Technical break and occupation dynamics in Brazil during middle Holocene”) URL: http://www.theses.fr/s32872

van Gijn, A.L. 2010, Flint in focus: Lithic biographies in the Neolithic and Bronze Age. Sidestone Press, Leiden, 289 p.

Keeley, L.H. 1980, Experimental determination of stone tools uses: A microwear analysis. The University of Chicago Press, Chicago and London, 226 p.

Lemorini, C. 2000, Reconnaître des tactiques d'exploitation du milieu au Paléolithique Moyen: La contribution de l'analyse fonctionnelle: Etude fonctionnelle des industries lithiques de Grotta Breuil (Latium, Italie) et de La Combette (Bonnieux, Vaucluse, France). British archaeological Reports - International Series Vol. 858. Archaeopress, Oxford 142 p. (in French) ("Recognising Middle Palaeolithic exploitation tactics: The contribution of functional analysis: Functional study of the lithic industries of Grotta Breuil (Lazio, Italy) and La Combette (Bonnieux, Vaucluse, France)”)

Lepot, M. 1993, Approche techno-fonctionnelle de l'outillage moustérien : essai de classification des parties actives en termes d'efficacité technique. Mémoire de Maîtrise thesis at Université Paris X- Nanterre, Nanterre, 170 p., 90 pl. p. (in French) ("Technofunctional approach to Mousterian tools: Attempt at classification of active parts in terms of technical efficiency")

Leroi Gourhan, A. 1973, Mileu et techniques (1973 ed.). Evolution et techniques. Editions Albin Michel, Paris, 475 p. (in French) (“Environment and techniques”) 
Lourdeau, A. 2010, Le tecnocomplexe Itaparica: définition Techno-funcionnelle des industries unifacialement à une face plane dans le centre et le nord-est du Brésil pendant la transition Pléistocène-Holocène et l'Holocène ancien. Doctorat en Préhistoire thesis at the École doctorale Milieux, cultures et sociétés du passé et du présent (Nanterre), Université Paris Ouest Nanterre La Défense, Nanterre, 477 p. (in French) ("The Itaparica tecnocomplex: Techno-funcional definition of unifacially industries on a flat face in central and north-eastern Brazil during the PleistoceneHolocene transition and the early Holocene")

URL: http://www.theses.fr/2010PA100190

Lourdeau, A. 2015, Lithic Technology and Prehistoric Settlement in Central and Northeast Brazil: Definition and Spatial Distribution of the Itaparica Technocomplex. PaleoAmerica, 1(1): 52-67. doi:10.1179/2055556314z.0000000005

Lucas, L.d.O. 2014, Mudanças técnicas da transição Pleistoceno-Holoceno ao Holoceno Médio no interior do Nordeste: indústrias líticas da sequência arqueológica da Toca do João Leite - PI. Mestrado - Arqueologia thesis at the Centro de Ciências Humanas Programa de Pós-Graduação em Arqueologia, Universidade Federal de Pernambuco, Recife, 164 p. (in Portuguese) (“Technical changes of the Pleistocene-Holocene transition to the Middle Holocene in the interior of the Northeast: Lithic industries of the archaeological sequence of the Toca do João Leite - PI”)

URL: https://repositorio.ufpe.br/handle/123456789/17181

Lycett, S.J. \& Eren, M.I. 2013, Levallois economics: An examination of 'waste’ production in experimentally produced Levallois reduction sequences. Journal of Archaeological Science, 40(5): 2384-2392. doi:10.1016/j.jas.2013.01.016

Marciani, G. 2013, The lithic assemblage of the US 13 at the Middle Paleolithic site of Oscurusciuto ( Ginosa , Taranto, Southern Italy): Technological studies. Master Erasmus Mundus em Quaternário e Pré-História thesis at the Departamento de Geologia da UTAD \& Departamento de Território, Arqueologia e Património do IPT, Instituto Politécnico de Tomar \& Universidade de Trás-os-Montes e Alto Douro, Tomar \& Vila Real, 163 p. URL: http://hdl.handle.net/10400.26/6019

Marciani, G., Spagnolo, V., Aureli, D., Ranaldo, F., Boscato, P. \& Ronchitelli, A. 2016, Middle Palaeolithic technical behaviour: Material import- export and Levallois production at the SU 13 of Oscurusciuto rock shelter, Southern Italy. Journal of Lithic Studies, 3(2): 1-24. doi:10.2218/jls.v3i2.1414

Moretti, E., Arrighi, S., Boschin, F., Crezzini, J., Aureli, D. \& Ronchitelli, A. 2015, Using 3D microscopy to analyze experimental cut marks on animal bones produced with different stone tools. Ethnobiology Letters, 6(2): 267-275. doi:10.14237/ebl.6.2.2015.349

Odell, G.H. 1981, The Mechanics of Use-Breakage of Stone Tools: Some Testable Hypotheses. Journal of Field Archaeology, 8(2): 197-209. doi:10.1179/009346981791505120

Odell, G.H. \& Odell-Vereecken, F. 1980, Verifying the Reliability of Lithic Use-Wear Assessments by 'Blind Tests': the Low-Power Approach. Journal of Field Archaeology, 7(1): 87-120. doi:10.1179/009346980791505545

Pedergnana, A. 2017, Microwear and residue analyses of quartzite stone tools. Experimental development of a method and its application to the assemblages from the Pleistocene sites of Gran Dolina-TD10 (Sierra de Atapuerca, Burgos, Spain) and Payre (Ardèche, 
France). Doctoral thesis at the Departament d'Història i Història de l'Art, Universitat Rovira i Virgili, Tarragona, 803 p. URL: http://hdl.handle.net/10803/454729

Van Peer, P. 1992, The Levallois reduction strategy. Monographs in world archaeology Vol. 13. Prehistory Press, Madison, Wisconsin, 137 p.

Plisson, H. 1985, Etude fonctionnelle d'outillages lithiques préhistoriques par l'analyse des micro-usures: recherche méthodologique et archéologique. Doctorat thesis at Université de Paris I, Paris, 357 p. (in French) ("Functional study of prehistoric lithic tools using micro-wear analysis: Methodological and archaeological research") URL: http://www.sudoc.fr/006727174 and https://www.academia.edu/1225018/

Plisson, H. 2007, La fonction des outils de silex dans les grottes ornées paléolithiques. In: Un siècle de construction du discours scientifique en préhistoire: Congrès du centenaire de la Société préhistorique française Vol. 3 (Evin, J., Ed.), Société Préhistorique Française, Paris: p. 125-132. (in French) ("The function of flint tools in Palaeolithic decorated caves”) URL: http://www.pacea.ubordeaux.fr/IMG/pdf/La_fonction_des_outils_de_silex_dans_les_grottes_ornees_paleol ithiques.pdf and https://halshs.archives-ouvertes.fr/halshs-00223017

Ramsey, C.B. \& Lee, S. 2013, Recent and planned developments of the program OxCal. Radiocarbon, 55(2): 720-730. doi:10.1017/s0033822200057878

Ranaldo, F. 2005, Il Musteriano del riparo l'Oscurusciuto nella gravina di Ginosa (TA): Studio tecnico e tipologico dell'industria litica dell'US1. Tesi di laurea thesis at the Laura Specialistica di II Livello in Archeologia. Facoltà di lettere e filosofia Siena, Università degli Studi di Siena, Siena, 171 p. (in Italian) ("The Mousterian of the Oscurusciuto rock shelter in the ravine of Ginosa (TA): Technical and typological study of the lithic industry of the US 1")

Ranaldo, F. 2017, L'arco ionico pugliese tra la fine del Paleolitico medio e gli esordi del Paleolitico superiore: problemi e prospettive di ricerca per la ricostruzione dei sistemi antropici. In: Preistoria E Protostoria Della Puglia (Radina, F., Ed.), Studi di preistoria e protostoria Vol. 4, Istitutolitaliano di Preistoria e Protostoria, Florence: p. 53-60. (in Italian) ("The Apulian Ionic arch between the end of the Middle Palaeolithic and the beginnings of the Upper Paleolithic: Problems and perspectives of research for the reconstruction of anthropic systems")

Reimer, P.J., Bard, E., Bayliss, A., Beck, J.W., Blackwell, P.G., Ramsey, C.B., Buck, C.E., Cheng, H., Edwards, R.L., Friedrich, M., Grootes, P.M., Guilderson, T.P., Haflidason, H., Hajdas, I., Hatté, C., Heaton, T.J., Hoffmann, D.L., Hogg, A.G., Hughen, K.A., Kaiser, K.F., Kromer, B., Manning, S.W., Niu, M., Reimer, R.W., Richards, D.A., Scott, E.M., Southon, J.R., Staff, R.A., Turney, C.S.M. \& van der Plicht, J. 2013, IntCal13 and Marine13 Radiocarbon Age Calibration Curves 0-50,000 Years cal BP. Radiocarbon, 55(4): 1869-1887. doi:10.2458/azu_js_rc.55.16947

Rocca, R. 2013, Peut-on définir des aires culturelles au Paléolithique inférieur ? Originalité des premières industries lithiques en Europe centrale dans le cadre du peuplement de l'Europe. Doctorat en Préhistoire thesis at the École doctorale Milieux, cultures et sociétés du passé et du présent (Nanterre), Université Paris X- Nanterre, Nanterre, 563 p. (in French) ("Can we define cultural areas during the Lower Palaeolithic? Originality of the first lithic industries in central Europe, in the framework of the first settlements in Europe”) URL: http://www.theses.fr/2013PA100060 
Ronchitelli, A., Ferguglia, M., Longo, L., Moroni, A. \& Ranaldo, F. 2011, Studio tecnofunzionale dei supporti a morfologia triangolare dell'US 8 del Riparo L'Oscurusciuto (Ginosa - Taranto). Rivista di Scienze Preistoriche, 61(5-20): 22-22. (in Italian) ("Techno-functional analysis of triangular tools from layer 8 of the Oscurusciuto Rock Shelter (Ginosa, Taranto - southern Italy)”)

Rots, V. 2010, Prehension and Hafting Traces on Flint Tools. A Methodology. Leuven University Press, Leuven, 296 p. URL: http://www.jstor.org/stable/j.ctt9qf05s

Schlanger, N. 1996, Understanding Levallois: Lithic Technology and Cognitive Archaeology. Cambridge Archaeological Journal, 6(02): 231-254. doi:10.1017/s0959774300001724

Simondon, G. 1958, Du mode d'existence des objets techniques. Philosophie. Aubier, Paris, 340 p. (in French) (“On the mode of existence of technical objects”)

Soriano, S. 2000, Outillage bifacial et outillage sur éclat au Paléolithique ancien et moyen : coexistence et interaction. Doctorat en Histoire thesis at Université Paris X- Nanterre, Nanterre, 459 p. (in French) ("Bifacial tools and flake tools of the Lower and Middle Palaeolithic: Coexistence and interaction”) URL: http://www.theses.fr/2000PA100137

Spagnolo, V. 2012, Analisi spaziale di un contesto musteriano: riparo l'Oscurusciuto (Ginosa - Ta). Tesi di laurea in Protostoria Europea thesis no. 10074504 at the Facoltà di Beni Culturali, Corso di Laurea Magistrale in Archeologia, Università del Salento, Lecce, 210 p. (in Italian) ("Spatial analysis of a Mousterian context: The Oscurusciuto shelter (Ginosa - Ta)”) URL: https://www.researchgate.net/publication/284723658

Spagnolo, V. 2017, Studio delle strategie insediative del Paleolitico Medio in Italia centromeridionale. Doctoral thesis at the Scienze della Terra, Ambientali e Polari, Università di Siena, Siena, 443 p. (in Italian) ("Study of settlement strategies of the Middle Palaeolithic in central-southern Italy”) URL: http://hdl.handle.net/11365/1011000

Spagnolo, V., Marciani, G., Aureli, D., Berna, F., Boscato, P., Ranaldo, F. \& Ronchitelli, A. 2016, Between hearths and volcanic ash: The SU 13 palimpsest of the Oscurusciuto rock shelter (Ginosa - Southern Italy): Analytical and interpretative questions. Quaternary International, 417: 105-121. doi:10.1016/j.quaint.2015.11.046

Tringham, R., Cooper, G., Odell, G., Voytek, B. \& Whitman, A. 1974, Experimentation in the Formation of Edge Damage: A New Approach to Lithic Analysis. Journal of Field Archaeology, 1(1-2): 171-196. doi:10.1179/jfa.1974.1.1-2.171

Villa, P., Boscato, P., Ranaldo, F. \& Ronchitelli, A. 2009, Stone tools for the hunt: points with impact scars from a Middle Paleolithic site in southern Italy. Journal of Archaeological Science, 36(3): 850-859. doi:10.1016/j.jas.2008.11.012 